Prepared in cooperation with the Bureau of Reclamation

\title{
Juvenile Lost River and Shortnose Sucker Year-Class Formation, Survival, and Growth in Upper Klamath Lake, Oregon and Clear Lake Reservoir, California-2017 Monitoring Report
}

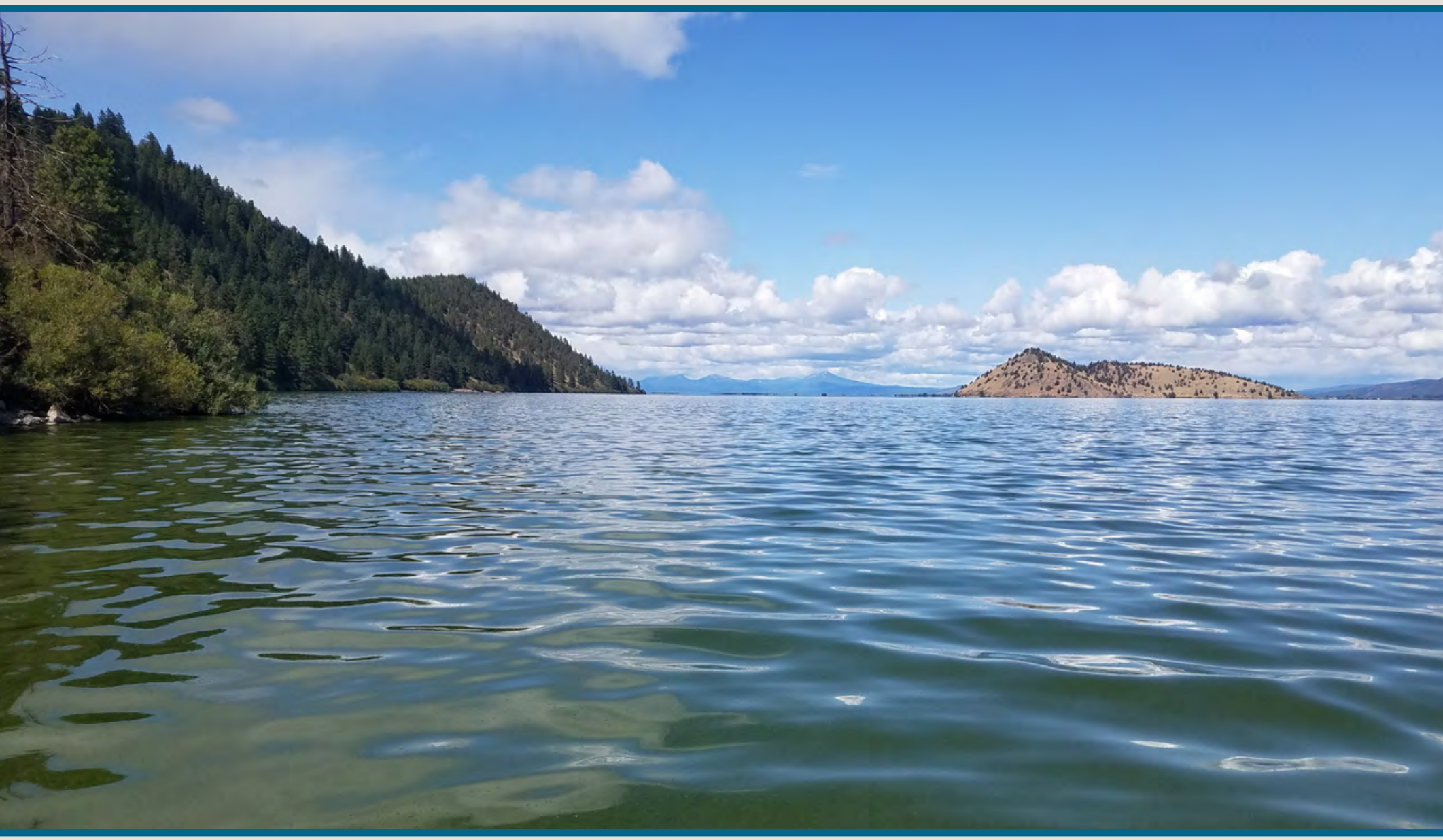

Open-File Report 2020-1025 
Cover: Upper Klamath Lake looking North to Bare Island (Photograph by Ryan Bart, U.S. Geological Survey, September 10, 2019). 


\section{Juvenile Lost River and Shortnose Sucker Year-Class Formation, Survival, and Growth in Upper Klamath Lake, Oregon and Clear Lake Reservoir, California-2017 Monitoring Report}

By Ryan J. Bart, Summer M. Burdick, Marshal S. Hoy, and Carl O. Ostberg

Open-File Report 2020-1025

Prepared in cooperation with the Bureau of Reclamation 


\title{
U.S. Department of the Interior \\ DAVID L. BERNHARDT, Secretary
}

\author{
U.S. Geological Survey \\ James F. Reilly, Director
}

U.S. Geological Survey, Reston, Virginia: 2020

For more information on the USGS-the Federal source for science about the Earth, its natural and living resources, natural hazards, and the environment-visit http://www.usgs.gov/ or call 1-888-ASK-USGS (1-888-275-8747).

For an overview of USGS information products, including maps, imagery, and publications, visit http://store.usgs.gov.

Any use of trade, firm, or product names is for descriptive purposes only and does not imply endorsement by the U.S. Government.

Although this information product, for the most part, is in the public domain, it also may contain copyrighted materials as noted in the text. Permission to reproduce copyrighted items must be secured from the copyright owner.

Suggested citation:

Bart, R.J., Burdick, S.M., Hoy, M.S., and Ostberg, C.O., 2020, Juvenile Lost River and shortnose sucker yearclass formation, survival, and growth in Upper Klamath Lake, Oregon and Clear Lake Reservoir, California2017 Monitoring Report: U.S. Geological Survey Open-File Report 2020-1025, 36 p., https://doi.org/10.3133/ofr20201025. 


\section{Contents}

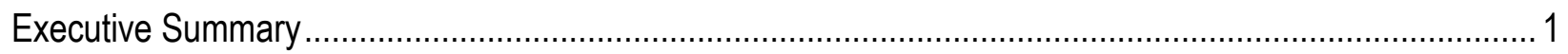

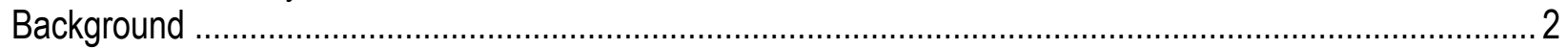

Study Area.

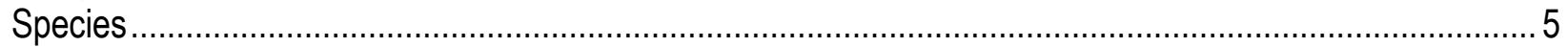

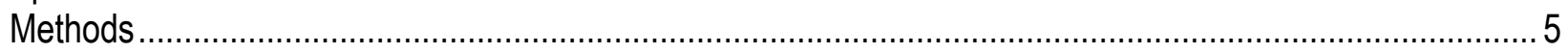

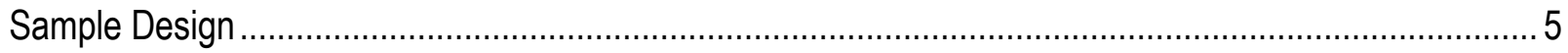

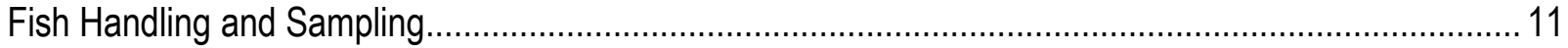

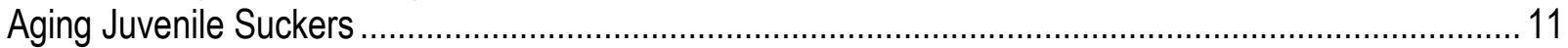

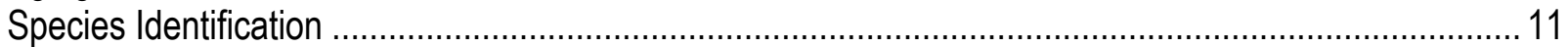

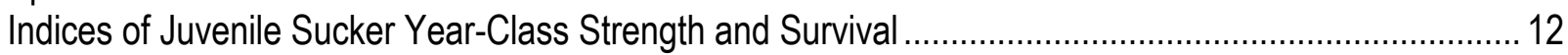

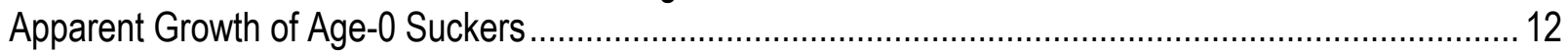

Observations on External Afflictions ........................................................................................... 13

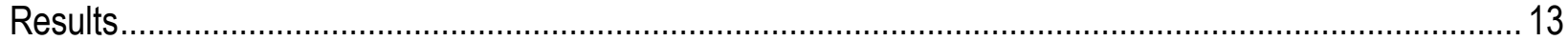

Upper Klamath Lake Year-Class Strength and Apparent Survival .................................................. 13

Clear Lake Year-Class Strength and Survival ................................................................................ 20

Length and Apparent Growth of Clear Lake Shortnose Suckers ....................................................... 24

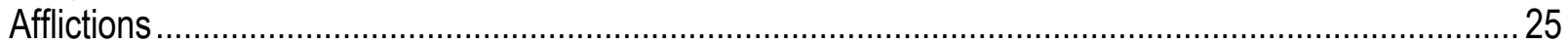

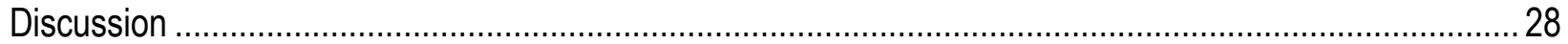

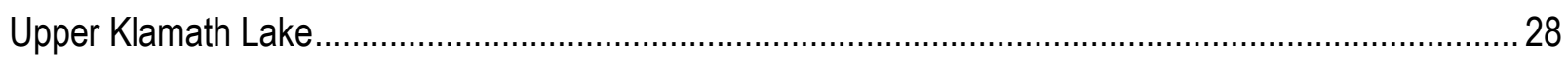

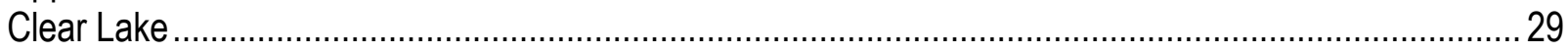

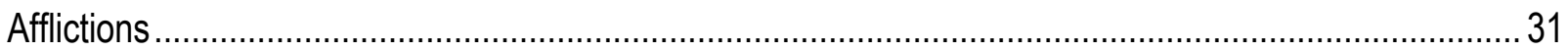

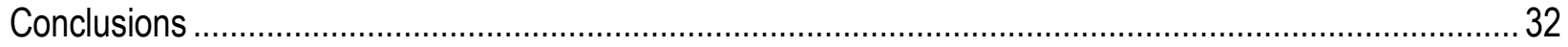

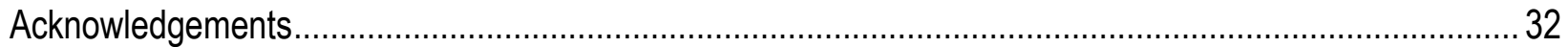

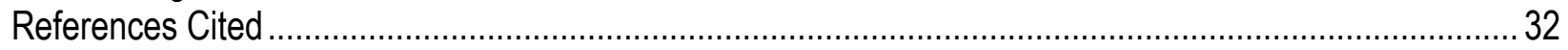

\section{Figures}

Figure 1. Locations of sample sites used to capture juvenile suckers in Upper Klamath Lake, Klamath

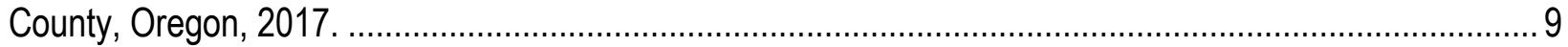

Figure 2. Locations of sample sites used to capture juvenile suckers in Clear Lake Reservoir,

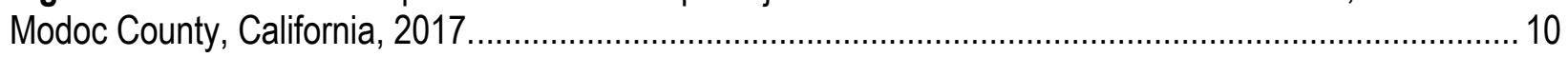

Figure 3. Number of annuli on suckers collected at Upper Klamath Lake, Oregon and Clear Lake, California, 2017.

Figure 4. Probability of taxa assignment as Lost River Sucker based on STRUCTURE (Prob[LRS]) at fixed sites in Upper Klamath Lake, Oregon, and Clear Lake, California, 2017 15

Figure 5. Standard lengths of age- 0 suckers collected at fixed locations in Upper Klamath Lake, Oregon, and Clear Lake, California

Figure 6. Standard length boxplot of the 2016 cohort of shortnose suckers from Clear Lake, California.... 25

Figure 7. Lake Surface elevations, Clear Lake Reservoir, California, 2014-17 


\section{Tables}

Table 1. Number of nets fished for juvenile suckers by area and sampling period in Upper Klamath Lake, Oregon, 2017.

Table 2. Number of nets fished for juvenile suckers by area and sampling period in Clear Lake

Reservoir, California, 2017.

Table 3. Number of total suckers captured, aged using fin rays, and identified to species using genetics from Clear Lake Reservoir, California and Upper Klamath Lake, Oregon, 2017.

Table 4. Catch per unit effort and percent of age-0 suckers for each taxa captured in Upper Klamath Lake, Oregon, and Clear Lake, California, in 2017.

Table 5. Catch statistics for August age-0 suckers from Upper Klamath Lake, Oregon for 2015, 2016, and 2017.

Table 6. August to September survival indices for age-0 suckers in each taxa captured in Upper Klamath Lake, Oregon.

Table 7. Catch statistics for the 2016 cohort of suckers from Upper Klamath Lake, Oregon........................ 18

Table 8. Catch statistics for the 2017 cohort of suckers from Upper Klamath Lake, Oregon...................... 19

Table 9. Catch statistics for the 2015 cohort of suckers from Clear Lake, California..................................21

Table 10. Catch statistics for the 2016 cohort of suckers from Clear Lake, California...............................22

Table 11. Catch statistics for the 2017 cohort of suckers from Clear Lake, California.............................. 23

Table 12. Catch statistics for August age-0 suckers from Clear Lake, California for 2015, 2016, and 2017.

Table 13. Proportions of age-0 suckers with attached Lernaea sp., Upper Klamath Lake, Oregon and Clear Lake, California, 2015, 2016 and 2017.

Table 14. Proportions of age-1 and older suckers with attached Lernaea sp., Upper Klamath Lake, Oregon and Clear Lake, California, 2015, 2016, and 2017

Table 15. Proportions of age-0 suckers in each of the three taxa that had petechial hemorrhages on the skin in Upper Klamath Lake, Oregon, and Clear Lake, California, 2015, 2016 and 2017.

Table 16. Proportions of age-1 and older suckers with petechial hemorrhages of the skin in Upper Klamath Lake, Oregon, and Clear Lake, California, 2015, 2016, and 2017.

Table 17. Proportions of age- 0 suckers in each of the three taxa with deformed opercula in Upper Klamath Lake, Oregon, and Clear Lake, California, 2015, 2016 and 2017.

Table 18. Proportions of age- 0 suckers in each of the three taxa with lamprey wounds in Upper Klamath Lake, Oregon, and Clear Lake, California, 2015, 2016 and 2017.

Table 19. Proportions of age-1 and older suckers with lamprey wounds in Upper Klamath Lake, Oregon, and Clear Lake, California, 2015, 2016 and 2017.

Table 20. Proportions of age-0 suckers in each of the three taxa with black spot in Upper Klamath Lake, Oregon and Clear Lake, California, 2015, 2016 and 2017. 


\section{Conversion Factors}

U.S. Customary Units to International System of Units

\begin{tabular}{lcc}
\hline \multicolumn{1}{c}{ Multiply } & By & To obtain \\
\hline & Length & \\
\hline millimeter $(\mathrm{mm})$ & 0.03937 & inch (in.) \\
kilometer $(\mathrm{km})$ & 0.6214 & mile (mi) \\
\hline & Area & \\
\hline millimeter squared $\left(\mathrm{mm}^{2}\right)$ & 0.00155 & inches squared $\left(\mathrm{in}^{2}\right)$ \\
\hline square kilometer $\left(\mathrm{km}^{2}\right)$ & 247.105 & acre \\
\hline
\end{tabular}

Temperature in degrees Celsius $\left({ }^{\circ} \mathrm{C}\right)$ may be converted to degrees Fahrenheit $\left({ }^{\circ} \mathrm{F}\right)$ as: ${ }^{\circ} \mathrm{F}=\left(1.8 \times{ }^{\circ} \mathrm{C}\right)+32$

Datum

Vertical coordinate information is referenced to the Bureau of Reclamation Vertical Datum.

Elevation, as used in this report, refers to distance above the vertical datum.

\section{Abbreviations}

$\mathrm{CL}$

LRS

PIT

SL

SNS

USBR

UKL

Clear Lake

Lost River sucker

passive integrated transponder

Standard Length

shortnose sucker

U.S. Bureau of Reclamation

Upper Klamath Lake 


\title{
Juvenile Lost River and Shortnose Sucker Year-Class Formation, Survival, and Growth in Upper Klamath Lake, Oregon and Clear Lake Reservoir, California-2017 Monitoring Report
}

\author{
By Ryan J. Bart, Summer M. Burdick, Marshal S. Hoy, and Carl O. Ostberg
}

\section{Executive Summary}

Populations of federally endangered Lost River (Deltistes luxatus) and shortnose suckers (Chasmistes brevirostris) in Upper Klamath Lake, Oregon, and Clear Lake Reservoir (hereinafter referred to as Clear Lake; fig. 1), California, are experiencing long-term declines in abundance. Upper Klamath Lake populations are decreasing because juvenile suckers are not surviving and recruiting into the adult population. Most juvenile sucker mortality occurs within the first year of life in Upper Klamath Lake. Annual production of juvenile suckers in Clear Lake appear to be highly variable and may not occur at all in very dry years. However, juvenile sucker survival is much higher in Clear Lake, with some suckers surviving to join spawning aggregations. Long-term monitoring of juvenile sucker populations is needed to 1) determine if there are annual and species-specific differences in production, survival, and growth; 2) better understand when juvenile sucker mortality is greatest; 3) help identify potential causes of high juvenile sucker mortality particularly in Upper Klamath Lake; and 4) monitor for successful juvenile survival in Upper Klamath Lake.

The U.S. Geological Survey (USGS) began a summer juvenile sucker monitoring program in 2015 to track cohorts over time in Upper Klamath and Clear Lakes. The juvenile sucker monitoring program involved using trap net data at fixed sites to determine the status of juvenile suckers. Annual variability in apparent age-0 sucker production, juvenile sucker survival, and growth were tracked. Using genetic markers, suckers were classified as one of three taxa; shortnose (combinations of shortnose and Klamath largescale suckers), Lost River, or suckers with genetic markers of both species (Intermediate [Prob]). By using catch data, we generated taxa-specific indices of year-class strength, August-September apparent survival, and overwinter apparent survival. We also examined the prevalence and severity of afflictions such as parasites, wounds, and deformities.

The Upper Klamath Lake year-class strength indices for both Lost River and shortnose suckers were slightly lower in 2015 and 2017 than in 2016. The ratios of age-0 Lost River suckers to age-0 shortnose suckers captured in August in Upper Klamath Lake were low in 2015 and 2017, given that adult Lost River suckers are more abundant and more fecund than adult shortnose suckers. This may indicate lower egg, larval, or juvenile survival or poorer spawning success for Lost River suckers than shortnose suckers in these two years. Apparent relative age-0 survival indices for Lost River suckers from August to September in Upper Klamath Lake were greater in 2015 (0.29) than in $2016(0.16)$ or 2017 (0.14). Age-0 shortnose sucker catch rates increased between August and September in 2015, possibly indicating new individuals of this species were still recruiting to the lake between the two 
sampling periods. August to September relative survival indices for Upper Klamath Lake shortnose suckers were 0.35 in 2016 and 0.00 in 2017.

We predicted year-class strength would be greater in Clear Lake in years when high spring-time lake elevations and instream flow allowed adult suckers access to spawning habitat in the Willow Creek drainage. Instream flows and lake elevations were sufficient to allow adult suckers to access Willow Creek during the 2016 and 2017 spawning seasons, and age-0 suckers were detected in Clear Lake both years. Higher lake surface elevations and instream flows in 2017 than in 2016 were not associated with higher year-class strength indices in 2017 than in 2016. Low lake surface elevations appeared to limit access by adults to Willow Creek during the 2014 and 2015 spawning seasons and age- 0 suckers were not detected in Clear Lake during these years. Nineteen shortnose suckers from the 2014 cohort were captured in Clear Lake in 2017. A 2015 cohort of shortnose suckers was captured as age-1 in 2016 and as age-2 in 2017. The most likely explanation for increasing catch rates of the 2015 cohort is that the higher Willow Creek flows in 2016 and 2017 facilitated the movement of stream-resident suckers, spawned in 2014 and 2015 downstream into Clear Lake. Due to uncertainty in the genetic identification of non-Lost River suckers, these fish are equally likely to be Klamath largescale or shortnose suckers (Hoy and Ostberg, 2015).

\section{Background}

Lost River sucker (Deltistes luxatus) and shortnose sucker (Chasmistes brevirostris) are both listed as endangered under the Endangered Species Act (U.S. Fish and Wildlife Service, 1988). Two of the remaining spawning populations of both Lost River sucker and shortnose sucker exist in Upper Klamath Lake (Klamath County, Oregon) and Clear Lake Reservoir (hereinafter referred to as Clear Lake; Modoc County, California; fig. 1) (U.S. Fish and Wildlife Service, 2013). The persistence of Upper Klamath Lake Lost River and shortnose sucker populations is threatened by a prolonged lack of recruitment into adult spawning aggregations (National Research Council, 2004; U.S. Fish and Wildlife Service, 2013). In fact, the last cohorts to join the current spawning population in Upper Klamath Lake were spawned in the early 1990s. The role of recruitment limitation to Clear Lake populations remains uncertain because year-classes appear to recruit intermittently but not infrequently (Hewitt and Hayes, 2013). In Upper Klamath Lake, decreasing catch rates of age-0 juvenile suckers during August and September in most years and a lack of age-1 or older juvenile sucker catches indicate that the lack of recruitment is due to high mortality within the first year or two of life (Burdick and Martin, 2017). In contrast, a more diverse age distribution of juvenile suckers has been documented in Clear Lake, indicating that juvenile sucker survival may be greater in Clear Lake relative to Upper Klamath Lake (Burdick, Elliott, and others, 2015).

Recovery of Lost River and shortnose sucker populations requires increasing the number of suckers that survive to maturity. A long-term monitoring program exists for adult suckers at spawning areas and is aimed at tracking recruitment into the spawning populations in Upper Klamath Lake and Clear Lake (Hewitt and others, 2015). This adult-sucker monitoring program has not detected substantial recruitment into spawning populations, as would be expected 4-7 years after suckers hatch. Relatively strong cohorts of age-0 suckers were detected in Upper Klamath Lake in 2006 and 2011, but substantial numbers of individuals from these cohorts did not appear to persist to age-2 (Simon and others, 2013; Burdick and Martin, 2017). Nor have these cohorts been detected in spawning populations as of the writing of this report (Hewitt and others, 2015; Burdick and Martin, 2017; Hewitt and others, 2018).

Hypothesized causes of juvenile sucker mortality include loss of habitat, poor water-quality, disease, parasites, and predation (mostly by birds) (Rasmussen, 2011); however, causes of high apparent 
juvenile mortality are unknown. To determine the causes and timing of juvenile sucker mortality and to monitor the long-term success of recovery actions, the U.S. Fish and Wildlife Service prioritized the assessment and monitoring of juvenile sucker populations in Upper Klamath Lake and Clear Lake (U.S. Fish and Wildlife Service, 2013; recovery actions 6.1 and 6.2).

Over the last two decades, research has been done, and monitoring data have been collected, on juvenile Lost River and shortnose suckers in Upper Klamath Lake. Juvenile suckers in Upper Klamath Lake were consistently monitored by Simon and others (2013) from 1997 to 2012. The USGS conducted various research projects from 2001 to 2010 and from 2012 to 2015 with the objectives of understanding habitat use, distribution, and health of age- 0 and age-1 juvenile suckers. Simon and others (2013) sampled with beach seines, cast nets, and trawls and used a study design that was consistent for several years, but the captured numbers of suckers were lower than the numbers captured by the USGS staff, who sampled with trap nets. Locations and sampling gears used were inconsistent across USGS research projects, making these data undesirable for monitoring long-term trends (Burdick and Martin, 2017). Nevertheless, the USGS analyzed data from their projects during their 15-year period of record to identify patterns in recruitment, survival, and growth of age-0 suckers in Upper Klamath Lake (Burdick and Martin, 2017). Simon and others' (2013) dataset indicates that the strongest year-classes for both species within the 16 years of their record probably occurred prior to 2001, and during 2011 (Simon and others, 2013). Relatively strong cohorts for both species also were produced in 2006 (Simon and others, 2013; Burdick and Martin, 2017). Because the Simon and others (2013) and USGS sampling occurred primarily in the summer, overwinter and summer to fall survival could not be assessed with data collected in either sampling program. USGS also cautioned that inconsistencies among years in the types of gear used, sample locations, and timing of sample collection limited inferences that could be made from their historical data.

The juvenile sucker monitoring program was initiated in 2015 with the intention of generating relative indices of juvenile Lost River and shortnose sucker production, growth, and survival in both Upper Klamath Lake and Clear Lake. This monitoring program aims to track cohorts both within and among years. The sample design used in this monitoring program addresses the issues of inconsistency identified by USGS and uses trap nets which are more efficient in catching suckers than active sampling gears such as cast nets, seines, and trawls. Data are anticipated to be useful for the identification of the environmental variables affecting the annual production and survival of young suckers. The dataset also will be useful for determining the collective effects of recovery actions on the production, survival, and growth of juvenile suckers. Through these monitoring efforts, long term trends will be identified and assist in the recovery of endemic suckers in the Upper Klamath Basin.

\section{Study Area}

Upper Klamath Lake is uniformly shallow, with an average water depth of $2.6 \mathrm{~m}$ and a surface area of $305 \mathrm{~km}^{2}$ at full pool (National Research Council, 2004). A 6.4-9.5-m-deep trench runs along the western shore of the lake. The primary inflows are through the Williamson River on the eastern shore and the smaller Wood River (fig. 1). A small but notable amount of water also upwells through the volcanic soils along the lakeshore and additional water enters the lake as precipitation. A natural volcanic reef at the outlet of the lake was replaced with a dam in 1921 to provide access to a greater volume of water for agriculture (National Research Council, 2004). The dam allows the lake surface elevation to range from about $1261.0 \mathrm{~m}(4137 \mathrm{ft})$ to $1262.8 \mathrm{~m}$ (4143 ft). All surface elevations are based on the Bureau of Reclamation vertical datum for the Upper Klamath Basin (U.S. Geological, 2019). Surface and groundwater inputs exceed down river flows from about October to June each year causing the lake volume to increase. Agricultural water deliveries, down river water releases to meet instream 
flow requirements, and to a lesser extent evaporation, exceed water inputs from around June to October each year causing the lake volume to decrease at a somewhat predictable rate. In 67 percent of the years on record (1974-2017), natural inflows replaced water withdrawals from the previous spring, such that the lake was at its maximum holding capacity by June (U.S. Geological Survey, 2019).

The bottom of Upper Klamath Lake is covered with fine organic detritus composed primarily of decaying diatoms and cyanobacteria. Shoreline wetlands in the northern part of the lake are heavily vegetated with wocus (Nuphar sp.), tules (Schoenoplectus acutus), and willows (Salix sp.). Massive annual blooms of the blue-green cyanobacterium Aphanizomenon flos-aquae (AFA) drive summer water-quality dynamics in Upper Klamath Lake (Eldridge, Caldwell Eldridge, and others, 2012). Algal blooms are associated with extremely dynamic dissolved oxygen concentrations that can range from supersaturation to anoxia within hours. Potential extreme summer water-quality conditions include: water temperatures greater than $24{ }^{\circ} \mathrm{C}$, dissolved-oxygen less than $2 \mathrm{mg} / \mathrm{L}$, $\mathrm{pH}$ greater than or equal to 10, and microcystin toxin concentrations 40-60 ppb (Eldridge, Caldwell Eldridge and others, 2012; Eldridge and others, 2012).

Clear Lake, located in the upper Lost River watershed, was historically a natural lake covering about 6,500 hectares (ha) (fig. 2). An associated wetland and meadow were located to the east of the lake. The Bureau of Reclamation built a dam on the Lost River near the lake outlet in 1910 to enable better seasonal water regulation. The dam enlarged the lake, which now inundates the wetland in most years, and expands the lake by about 3,900 ha (Buettner and Scoppettone, 1991). The present day Clear Lake has two distinct parts that are connected by a wide shallow channel: the shallower former marsh on the eastern side, and the deeper historical lake on the western side. Willow Creek, which has the only known spawning area and provides the only substantial inflows, enters the eastern lobe of the reservoir near the dam. Inflows primarily occur in the winter or spring and the tributaries become intermittent in midsummer. Water is released through the Clear Lake Dam into the Lost River to provide spring and summer irrigation to the Langell Valley in Oregon. At a lake surface elevation of about 1,378.6 m $(4,523 \mathrm{ft})$, the two parts of the lake become disconnected. At lake-surface elevations around 1,378.9 $\mathrm{m}$ $(4,524 \mathrm{ft})$, access to Willow Creek is impeded for spawning suckers (National Marine Fisheries Service and U.S. Fish and Wildlife Service, 2013). Water can be delivered down the river below the point of disconnection between the lobes until the lake surface elevation reaches the operational floor of 1,378.3 $\mathrm{m}(4,522 \mathrm{ft})$. The eastern lobe almost completely dries out when the lake surface elevation declines to about 1,377.7 $\mathrm{m}(4,520 \mathrm{ft})$, which happened in 2014 and 2015. Because of these dynamics, the lake depth can fluctuate by more than 3 m among and within years (U.S. Bureau Reclamation, 2019).

Clear Lake is in the U.S. Fish and Wildlife Service's Clear Lake National Wildlife Refuge, and the upper watershed is almost entirely located within the U.S. Forest Service's Modoc and Fremont National Forests. The area around the lake is rocky with sagebrush (Artemesia sp.) steppe plant communities and western juniper (Juniperus occidentalis), whereas the upper watershed is a ponderosa pine (Pinus ponderosa) forest (Buettner and Scoppettone, 1991). The bottom of Clear Lake is covered with claylike sediment and occasional large lava rocks. The lake is turbid, which is likely the result of wind coupled with shallow water and fine sediments. Summer water temperatures have greater diel fluctuations and water quality is generally better than in Upper Klamath Lake: water temperatures are as high as $26^{\circ} \mathrm{C}$, dissolved-oxygen greater than or equal to $5 \mathrm{mg} / \mathrm{L}, \mathrm{pH}$ around 8.5 , and no detectable microcystin toxin (Burdick, Elliott, and others, 2015). 


\section{Species}

Lost River and shortnose suckers are long-lived lake dwelling catostomids that make springtime spawning migrations to lake shores or tributaries beginning at ages 4 through 7 (Hewitt and others, 2015). Upper Klamath Lake populations typically spawn from March to June, whereas Clear Lake populations spawn from February to April (Hewitt and Hayes, 2013; Burdick, Hewitt, and others, 2015). Spawning migrations start when tributary water temperatures exceed $10^{\circ} \mathrm{C}$ in Upper Klamath Lake and approximately $6^{\circ} \mathrm{C}$ in Clear Lake. Larvae of Upper Klamath Lake river spawning populations outmigrate at night in May and early June to in-lake rearing habitats within several days of emerging from gravel (Cooperman and Markle, 2003). Clear Lake sucker larvae out-migrate from Willow Creek during April and May (Sutphin and Tyler, 2016). Age-0 juvenile suckers of both taxa are widely distributed throughout Upper Klamath Lake by late July and August, and there is no evidence of directed migrations during this time period (Hendrixson, and others, 2007; Burdick and others, 2009; Burdick and Hewitt, 2012). Age-1 suckers are much less abundant than age-0 suckers and immature suckers age2 and older are rarely encountered in Upper Klamath Lake. The oldest Lost River sucker sampled was estimated to be 57 years old, and the oldest shortnose sucker was estimated to be 33 years old (Terwilliger and others, 2010).

Historically, both species were abundant enough to support a subsistence fishery; however, decreasing population trends started to become evident by the 1960s (Markle and Cooperman, 2002). Regular recruitment to the spawning populations in Upper Klamath Lake has not been documented since the early 1970s (Scoppettone 1986; Terwilliger and others, 2010). The fishery was eventually closed in 1987 (Janney and others, 2008), but poor survival of juvenile suckers persisted in Upper Klamath Lake populations after the closure of the fishery. While adult survival is typically high, populations are limited by occasional (sometimes massive) adult fish die-off events and little to no recruitment to the spawning populations (Hewitt and others, 2018).

\section{Methods}

\section{Sample Design}

We sampled for suckers with trap nets to assess species-specific annual variability in production and growth, and annual and seasonal variability in survival of juvenile suckers in Upper Klamath Lake and Clear Lake. The timing of the sampling periods was chosen on the basis of previous catch data in Upper Klamath Lake. Specifically, we targeted age-1 suckers in early June, the typical peak of age-0 sucker catches in August, and the decreasing age-0 sucker catches in September (Burdick and Martin, 2017). In 2015 sampling was conducted over three three-week periods simultaneously in both Upper Klamath and Clear lakes. An evaluation of the study design used in 2015 indicated that, with increased effort concentrated within shorter time periods, we could better describe growth and differences in catch rates between sampling periods. In each sampling month in 2016 and 2017, sampling events were within 1 week intervals within each lake and lakes were sampled in sequential weeks within each month.

Given the limitations of our chosen gear type, our analysis of catch data is relevant only to suckers between about 45 and $230 \mathrm{~mm}$ SL (standard length). Trap nets are likely size-selective for fish of an intermediate size range, which may have led to underrepresentation of both age- 0 and suckers larger than approximately 230-300 $\mathrm{mm}$ SL. Fish small enough to pass through the mesh of our nets, such as small age- 0 suckers (less than $45 \mathrm{~mm}$ SL), have a low catchability in trap nets (Burdick and Martin, 2017). Because adult suckers (greater than $300 \mathrm{~mm} \mathrm{SL}$ ) are captured at high rates in spring and 
fall trammel net sampling and infrequently in summer trap net sampling, we presume trap nets select for smaller suckers relative to trammel nets (Hewitt and Hayes, 2013). Burdick and others (2016) did not find a length based pattern in the proportions of PIT tagged and released suckers (70-229 $\mathrm{mm} \mathrm{SL})$ that were recaptured, indicating no strong size selectivity within this size range.

To reduce potential sampling bias caused by apparently minor spatial heterogeneity in the densities, species, ages, size, or health of suckers, we selected fixed sample sites in a variety of habitats throughout both lakes. Age- 0 suckers of at least $40 \mathrm{~mm} \mathrm{SL}$, the size targeted in our sampling, are not known to be distributed differentially within Upper Klamath Lake based on species or size (Hendrixson and others, 2007; Burdick and Hewitt, 2012). However, age-1 suckers are more likely to be found in shallow (less than $1 \mathrm{~m}$ deep) near-shore habitats in the spring and in water around $2 \mathrm{~m}$ deep in the summer (Bottcher and Burdick, 2010). Spatial patterns among age classes of suckers have not been identified in Clear Lake (Burdick and Rasmussen, 2012).

Sampling areas were either 1-km long sections of shoreline or offshore areas of 300 square meters. Within each area, 10 fixed sites were identified as potentially accessible given a variety of water levels. In 2017, 8 sites at each area in Upper Klamath Lake and 7 sites in each area in Clear Lake were sampled during each sampling period (tables 1 and 2) with the exception of Tulana which is not as accessible when levels in Upper Klamath Lake are lower. To address the concern of inadvertent bias in our fixed-site selection, randomly determined site locations were sampled in 2016; however, we found no significant difference between fixed and random sites (Burdick and others, 2016). With no significant difference found in 2016, randomly determined sites were excluded from all subsequent analyses described in this report.

Due to high lake surface elevations in 2017 in Clear Lake, sample sites that were shallow and near shore in 2015 and 2016 were often in more than $3 \mathrm{~m}$ of water and far from shore in 2017. In June of 2017, we continued to sample the sites used in 2015 and 2016. Because juvenile sucker catch rates with trap nets decrease below about $3 \mathrm{~m}$ of depth (Burdick and Hewitt, 2012), we captured very few juvenile suckers. Therefore, we decided to change sampling sites slightly in August and September. New site locations were determined by going to the 2015 and 2016 locations, then driving directly toward shore from the original site until we were in less than $3 \mathrm{~m}$ of water before setting the nets. 
Table 1. Number of nets fished for juvenile suckers by area and sampling period in Upper Klamath Lake, Oregon, 2017.

\begin{tabular}{|c|c|c|c|c|c|}
\hline \multirow{2}{*}{ Area } & \multirow{2}{*}{ Latitude } & \multirow{2}{*}{ Longitude } & \multicolumn{3}{|c|}{2017 Number of Nets Set } \\
\hline & & & June 12-16 & August 7-11 & September 18-22 \\
\hline Wood River Mouth & $42^{\circ} 34^{\prime} 18.84^{\prime \prime} \mathrm{N}$ & $121^{\circ} 56^{\prime} 27.44^{\prime \prime} \mathrm{W}$ & 8 & 8 & 8 \\
\hline Fish Banks North & $42^{\circ} 28^{\prime} 53.18^{\prime \prime} \mathrm{N}$ & $122^{\circ} 3^{\prime} 22.89^{\prime \prime} \mathrm{W}$ & 8 & 8 & 8 \\
\hline Fish Banks South & $42^{\circ} 26^{\prime} 25.19^{\prime \prime} \mathrm{N}$ & $122^{\circ} 3^{\prime} 20.45^{\prime \prime} \mathrm{W}$ & 8 & 8 & 8 \\
\hline Pelican Bay & $42^{\circ} 27^{\prime} 48.44^{\prime \prime} \mathrm{N}$ & $122^{\circ} 4^{\prime} 37.62^{\prime \prime} \mathrm{W}$ & 8 & 8 & 8 \\
\hline Tulana & $42^{\circ} 29^{\prime} 5.56^{\prime \prime} \mathrm{N}$ & $121^{\circ} 57^{\prime} 19.40^{\prime \prime} \mathrm{W}$ & 8 & 8 & 0 \\
\hline Shoalwater Bay & $42^{\circ} 25^{\prime} 16.54^{\prime \prime} \mathrm{N}$ & $121^{\circ} 57^{\prime} 45.27^{\prime \prime} \mathrm{W}$ & 8 & 8 & 8 \\
\hline Hagelstein & $42^{\circ} 23^{\prime} 0.79^{\prime \prime} \mathrm{N}$ & $121^{\circ} 48^{\prime} 56.44^{\prime \prime} \mathrm{W}$ & 8 & 8 & 8 \\
\hline Howard Bay & $42^{\circ} 20^{\prime} 49.72^{\prime \prime} \mathrm{N}$ & $121^{\circ} 54^{\prime} 57.38^{\prime \prime} \mathrm{W}$ & 8 & 8 & 8 \\
\hline Hanks Marsh & $42^{\circ} 18^{\prime} 17.85^{\prime \prime} \mathrm{N}$ & $121^{\circ} 50^{\prime} 13.72^{\prime \prime} \mathrm{W}$ & 8 & 8 & 8 \\
\hline Moore Park & $42^{\circ} 14^{\prime} 6.57^{\prime \prime} \mathrm{N}$ & $121^{\circ} 48^{\prime} 46.31^{\prime \prime} \mathrm{W}$ & 8 & 8 & 8 \\
\hline Mid-North & $42^{\circ} 26^{\prime} 0.91^{\prime \prime} \mathrm{N}$ & $122^{\circ} 0^{\prime} 56.35^{\prime \prime} \mathrm{W}$ & 0 & 8 & 8 \\
\hline Rattlesnake Point & $42^{\circ} 20^{\prime} 34.57^{\prime \prime} \mathrm{N}$ & $121^{\circ} 51^{\prime} 3.79^{\prime \prime} \mathrm{W}$ & 0 & 8 & 8 \\
\hline Total nets set & & & 80 & 96 & 88 \\
\hline
\end{tabular}


Table 2. Number of nets fished for juvenile suckers by area and sampling period in Clear Lake Reservoir, California, 2017.

\begin{tabular}{lllcc}
\hline \multicolumn{1}{c}{ Area } & \multicolumn{1}{c}{ Latitude } & Longitude & 2017 Number of Nets Set \\
\cline { 2 - 5 } & \multicolumn{1}{c}{ Sune 5-9 } & August 14-18 \\
\hline $\begin{array}{c}\text { Dam to Willow Creek } \\
\text { mouth (Dam Channel) }\end{array}$ & $41^{\circ} 55^{\prime} 24.80^{\prime \prime} \mathrm{N}$ & $121^{\circ} 4^{\prime} 56.75^{\prime \prime} \mathrm{W}$ & 7 & 7 \\
The Rocks & $41^{\circ} 53^{\prime} 25.75^{\prime \prime} \mathrm{N}$ & $121^{\circ} 10^{\prime} 26.15^{\prime \prime} \mathrm{W}$ & 7 & 7 \\
West Mouth of Straits & $41^{\circ} 52^{\prime} 58.76^{\prime \prime} \mathrm{N}$ & $121^{\circ} 9^{\prime} 35.24^{\prime \prime} \mathrm{W}$ & 7 & 7 \\
Section A & $41^{\circ} 53^{\prime} 31.72^{\prime \prime} \mathrm{N}$ & $121^{\circ} 13^{\prime} 21.14^{\prime \prime} \mathrm{W}$ & 7 & 7 \\
West Shore & $41^{\circ} 51^{\prime} 48.77^{\prime \prime} \mathrm{N}$ & $121^{\circ} 12^{\prime} 28.12^{\prime \prime} \mathrm{W}$ & 7 & 7 \\
Last Chance Island & $41^{\circ} 52^{\prime} 11.56^{\prime \prime} \mathrm{N}$ & $121^{\circ} 9^{\prime} 10.31^{\prime \prime} \mathrm{W}$ & 7 & 7 \\
Vegetation Patch & $41^{\circ} 51^{\prime} 4.47^{\prime \prime} \mathrm{N}$ & $121^{\circ} 12^{\prime} 40.10^{\prime \prime} \mathrm{W}$ & 7 & 7 \\
South Rock Reef & $41^{\circ} 50^{\prime} 47.41^{\prime \prime} \mathrm{N}$ & $121^{\circ} 9^{\prime} 34.39^{\prime \prime} \mathrm{W}$ & 7 & 7 \\
South Shore & $41^{\circ} 49^{\prime} 11.02^{\prime \prime} \mathrm{N}$ & $121^{\circ} 8^{\prime} 34.03^{\prime \prime} \mathrm{W}$ & 7 & 7 \\
Southwest Shore & $41^{\circ} 50^{\prime} 0.46^{\prime \prime} \mathrm{N}$ & $121^{\circ} 11^{\prime} 7.77^{\prime \prime} \mathrm{W}$ & 7 & 7 \\
\hline Total nets set & & & 70 & 7 \\
\hline
\end{tabular}




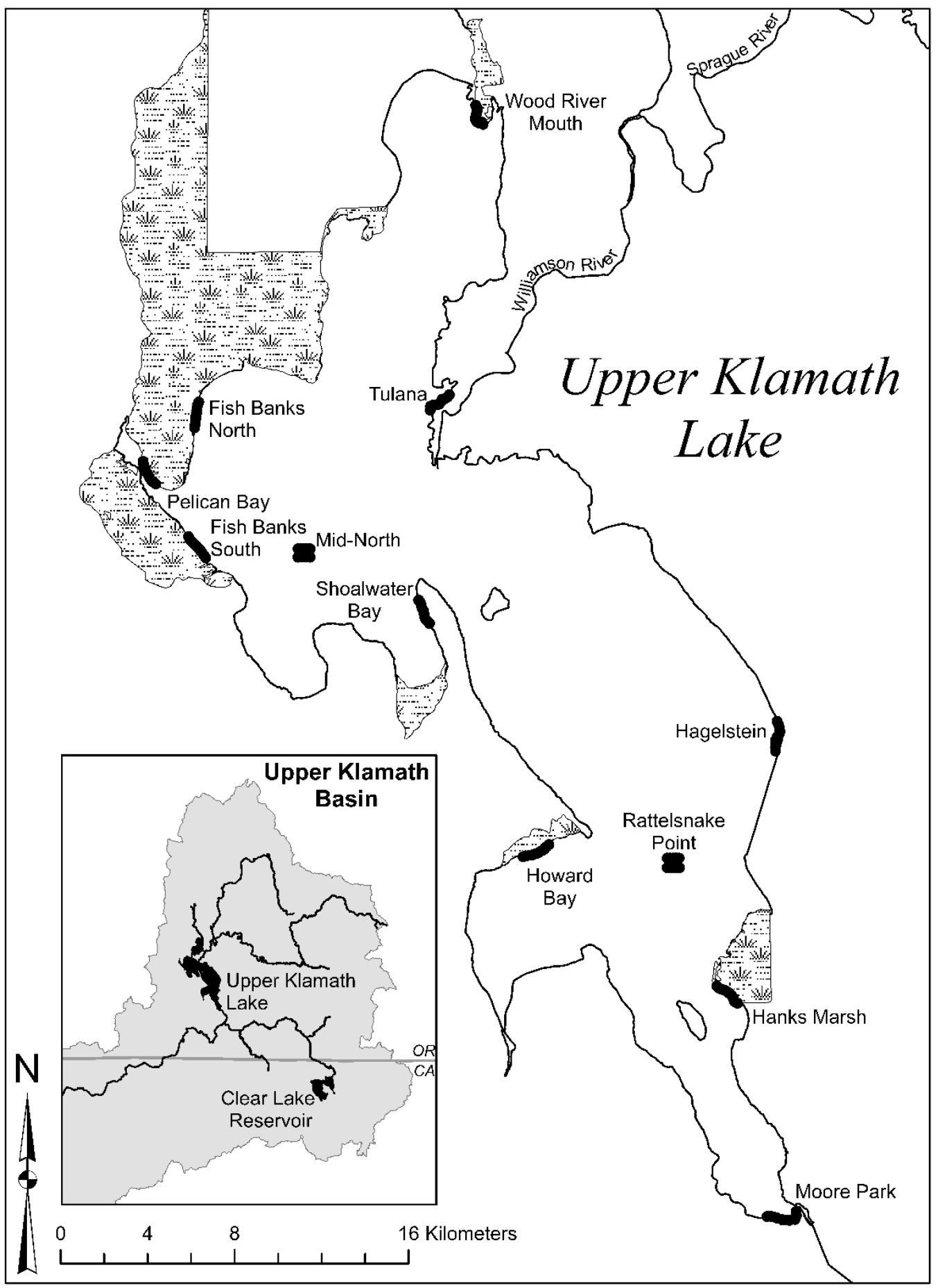

Figure 1. Locations of sample sites used to capture juvenile suckers in Upper Klamath Lake, Klamath County, Oregon, 2017. 


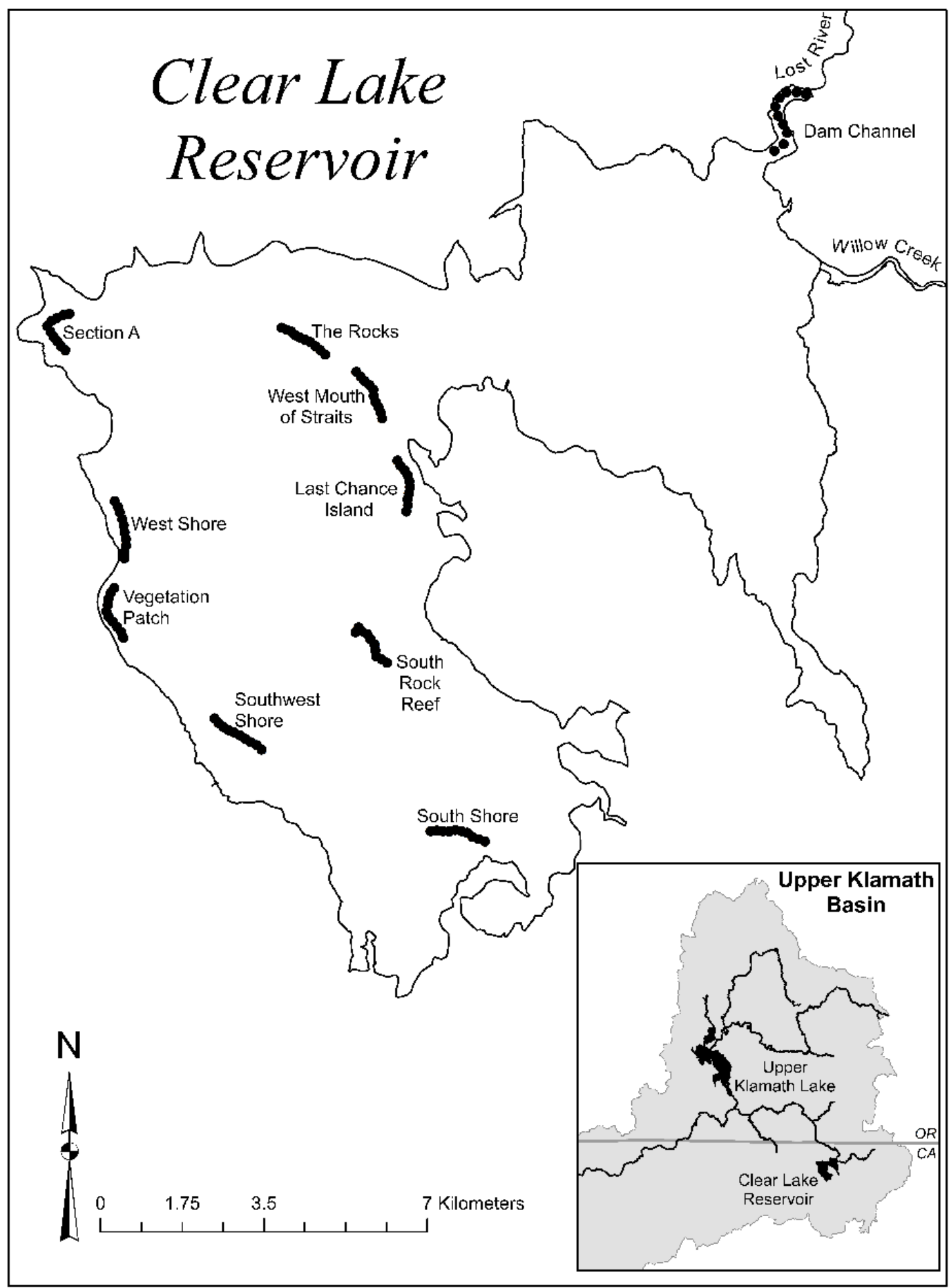

Figure 2. Locations of sample sites used to capture juvenile suckers in Clear Lake Reservoir, Modoc County, California, 2017. 


\section{Fish Handling and Sampling}

Sampling was conducted with rectangular trap nets with mouth dimensions of $0.61 \times 0.91 \mathrm{~m}$, a 10-m-lead, and three internal fykes. SL and fork length were recorded for each captured individual. The leading left pectoral fin ray was removed at the proximal joint for aging. Fin rays were not collected from small suckers (37-63 mm SL) from Upper Klamath Lake because they were presumed to be age-0 fish based on length at date of capture (Burdick and Martin, 2017). We compared the lengths and number of annuli on juveniles with fin rays collected to the length of suckers without fin rays collected to validate our length-based age assumptions. A small (about $2 \mathrm{~mm}^{2}$ ) piece of tissue from the caudal fin was collected to determine taxa. The numbers of suckers from which age and genetic samples were collected and analyzed are given in table 3. Emaciation, deformities, macro parasites, petechial skin hemorrhaging, and gill abnormalities were systematically recorded. Other abnormalities and afflictions were noted as they were observed. Suckers were either released at their site of capture or sacrificed for other research.

Table 3. Number of total suckers captured, aged using fin rays, and identified to species using genetics from Clear Lake Reservoir, California and Upper Klamath Lake, Oregon, 2017.

\begin{tabular}{llc}
\hline \multicolumn{1}{c}{ Number of Suckers } & $\begin{array}{c}\text { Clear Lake } \\
\text { Reservoir }\end{array}$ & $\begin{array}{c}\text { Upper Klamath } \\
\text { Lake }\end{array}$ \\
\hline Aged & 144 & 48 \\
Genetic identification & 144 & 44 \\
Total captured & 148 & 48 \\
\hline
\end{tabular}

\section{Aging Juvenile Suckers}

To estimate sucker age, fin rays were mounted in epoxy, sectioned, and viewed by two experienced readers under magnification using transmitted light (Quist and others, 2012). The number of annuli was first determined in blind reads with each reader having no knowledge of the other's annuli count. When both readers agreed on a number of annuli, that number was presumed to be the correct age and was used in analyses. If there was disagreement in the annuli count, the two readers viewed the structure together and came to a consensus, or a third reader acted as a tie breaker. All the suckers from Upper Klamath Lake were aged. Four Clear Lake suckers, not within the length bin (less than $63 \mathrm{~mm}$ ) systematically assumed to be age- 0 were not aged due to no fin ray being collected.

\section{Species Identification}

To identify juvenile suckers to taxa, we applied genetic identification methods described by Hoy and Ostberg (2015). Caudal fin tissue was collected and dried from all but four juvenile suckers. Deoxyribonucleic acid (DNA) was extracted from the caudal tissues by using DNeasy kits (Qiagen, Inc. ${ }^{\circledR}$, Valencia, California). A total of eighteen nuclear DNA TaqMan ${ }^{\circledR}$ assays were used to differentiate the species based on single nucleotide polymorphisms (SNPs) (Hoy and Ostberg, 2015).

We used the program STRUCTURE, version 2.3 (Pritchard and others, 2000; Evanno and others, 2005), to probabilistically assign individual multilocus genotypes to the sampled juvenile suckers based on the posterior distribution of the program output. STRUCTURE uses a Markov chain Monte Carlo (MCMC) simulation approach to identify the posterior probability (q) for the proportion of an individual genotype derived from each of K population clusters. We applied the admixture model with independent allele frequencies, given the high differentiation between Lost River and shortnose 
suckers. A total of 10 repetitions were run in STRUCTURE, and the model parameters were as follows: (1) markers assumed to be unlinked; (2) 18 nuclear loci; (3) two populations assumed; and (4) 50,000 burn-in steps, followed by 100,000 MCMC iterations. We followed the procedure of Evanno and others (2005) to estimate the most probable number of K population clusters. The most probable number of population clusters was $\mathrm{K}=2$ (that is, Lost River and shortnose suckers). Therefore, admixture proportions between Lost River and shortnose suckers were estimated for each individual using the mean posterior probability over the 10 repetitions.

Single nucleotide polymorphisms available for species identification cannot distinguish shortnose suckers from co-occurring Klamath largescale suckers. Throughout this report, we call the non-Lost River sucker taxa shortnose suckers, although we acknowledge they are likely a combination of both shortnose and Klamath largescale suckers. For data analysis we categorized suckers having a Prob[LRS] $\geq 0.95$ as Lost River sucker, those with a Prob [LRS] $\leq 0.05$ as shortnose sucker, and fish with a Prob[LRS] intermediate of the two values "Intermediate Prob[LRS]" (Burdick and others, 2016).

\section{Indices of Juvenile Sucker Year-Class Strength and Survival}

To describe annual relative (among cohorts, species, and lakes) year-class strength and apparent age-0 sucker production we calculated (1) the proportion of August nets to catch one or more age-0 sucker (successful age-0 nets), (2) the mean August catch per unit effort (CPUE) for age-0 suckers in successful age- 0 nets, and (3) the total August age-0 CPUE as the number of suckers in each taxa divided by the number of nets set. We assessed age- 0 summer survival by comparing CPUE by yearclass between the August and September sampling periods. This comparison gave us an index of apparent survival between sampling periods to best indicate when the most mortality is happening. To provide an index of overwinter survival, the CPUE for each year-class was compared between September and the following June.

We assumed that sampling efficiency was similar among different years and within one-year sampling periods. The presence of vegetation, substrate type, and water depth had minor effects on the detection probability of juvenile suckers (Burdick, Wilkens, and VanderKooi, 2008). By using the same fixed sites throughout fairly homogenous habitat with little to no vegetation, we ensured that habitat variables were similar at sampled sites between years. Furthermore, water management in Upper Klamath Lake ensured that water depth is similar each August and therefore did not differentially affect capture probability. Water depth decreases at a similar rate in Upper Klamath Lake between August and September sample periods and increases again each year. Therefore, a smaller water volume could cause higher fish density and capture probability given the same number of fish in September than in August, and in September than in June. For this reason, we caution that our survival indices are not actual measures of survival, and over summer and over winter indices are not necessarily comparable to each other. The indices are useful for comparing year-class strength and apparent survival among years.

\section{Apparent Growth of Age-0 Suckers}

We used graphical analysis to examine change-in-length data among sampling periods for shortnose suckers from the 2016 cohort captured in Clear Lake. Due to low catch rates of all other age classes and taxa in both lakes, there were no other groups of fish with a large enough sample size to warrant an analysis of growth. 


\section{Observations on External Afflictions}

We summarized the prevalence and intensity of external afflictions on juvenile suckers as a way to roughly compare the apparent health of suckers between years and lakes and potentially identify causes of sucker mortality. We paid special attention to those afflictions that are either common or potentially associated with mortality (Markle and others, 2014; Burdick, Elliott, and others, 2015). These included petechial hemorrhaging of the skin, opercular deformities, black spots (presumed to be encysted metacercariae of the trematode Bolbophorus sp.), Lernaea sp, and lamprey wounds. Lernaea $\mathrm{sp}$. is an ectoparasitic copepod that can cause severe inflammation at the attachment site and may possibly provide a pathway for bacterial infection (Berry and others, 1991). Petechial hemorrhages on fish have been found to be caused by any number of irritants including, bacteria, toxins, and (or) abrasion (Ferguson and others, 2011). Afflictions were then quantified and compared to observed afflictions relative to previous years.

\section{Results}

\section{Upper Klamath Lake Year-Class Strength and Apparent Survival}

Forty-eight suckers were captured in Upper Klamath Lake during the 2017 juvenile monitoring sampling, most of which ( 71 percent) were age-0 (table 4, fig. 3 ). The proportion of the total catch that was age-0 in Upper Klamath Lake in 2017 was lower than in 2015 and 2016, due to lower catch rates for age-0 suckers and is not due to higher catch rates of other age classes. Of the 34 age- 0 suckers captured in Upper Klamath Lake, 8 were Lost River suckers, 14 were shortnose suckers, 12 were an intermediate prob [LRS] (table 4, fig. 4).

Year-class strength and survival indices varied between species and among years in Upper Klamath Lake. Indices of annual year-class strength, calculated as August CPUE, were larger for the 2016 cohort than the 2017 and 2015 cohorts (table 5, fig. 5). A greater CPUE in 2016 than other years appeared to be driven by greater catches of Lost River suckers rather than shortnose suckers, or a combination of the two species (table 5). August to September survival indices were greater for age-0 Lost River suckers in 2015 than in 2016 or 2017 (table 6). August to September survival indices were greater for age-0 shortnose suckers in 2016 than 2017 (table 6). Catch rates for age-0 shortnose suckers increased from August to September of 2015, indicating that this species may have still been recruiting age- 0 fish to the lake at the end of the summer of 2015. Due to low catches, overwinter survival indices (June age-1 CPUE/September age-0 CPUE) by sucker species were not calculated, but they were for all species combined. Winter survival indices were 0.32 for the 2015 cohort and 0.23 for the 2016 cohort.

Cohort tracking among years indicated that first and second year apparent survival of suckers was very low in Upper Klamath Lake, with no apparent survival to age-2. Small 2015 and 2016 cohorts of both Lost River and shortnose suckers were detected in their first year of life. The last detection of each 2015 and 2016 cohort of Lost River suckers was a single fish captured as age-1 during the second June of its life (Burdick and others, 2018; table 7). The last detection of each 2015 and 2016 cohort of shortnose suckers was a single fish captured as age-1 during the second August of its life. During the 2017 sampling season, there were only nine age-1 suckers caught; six of which were captured in June. The 2017 cohort in Upper Klamath Lake appeared to decrease faster than the 2016 cohort with only one individual (a Lost River sucker) caught during the September 2017 sampling period (tables 7 and 8). The total numbers of sucker captured in 2017 were small, which limits our ability to infer differences in survival rates between cohorts. 


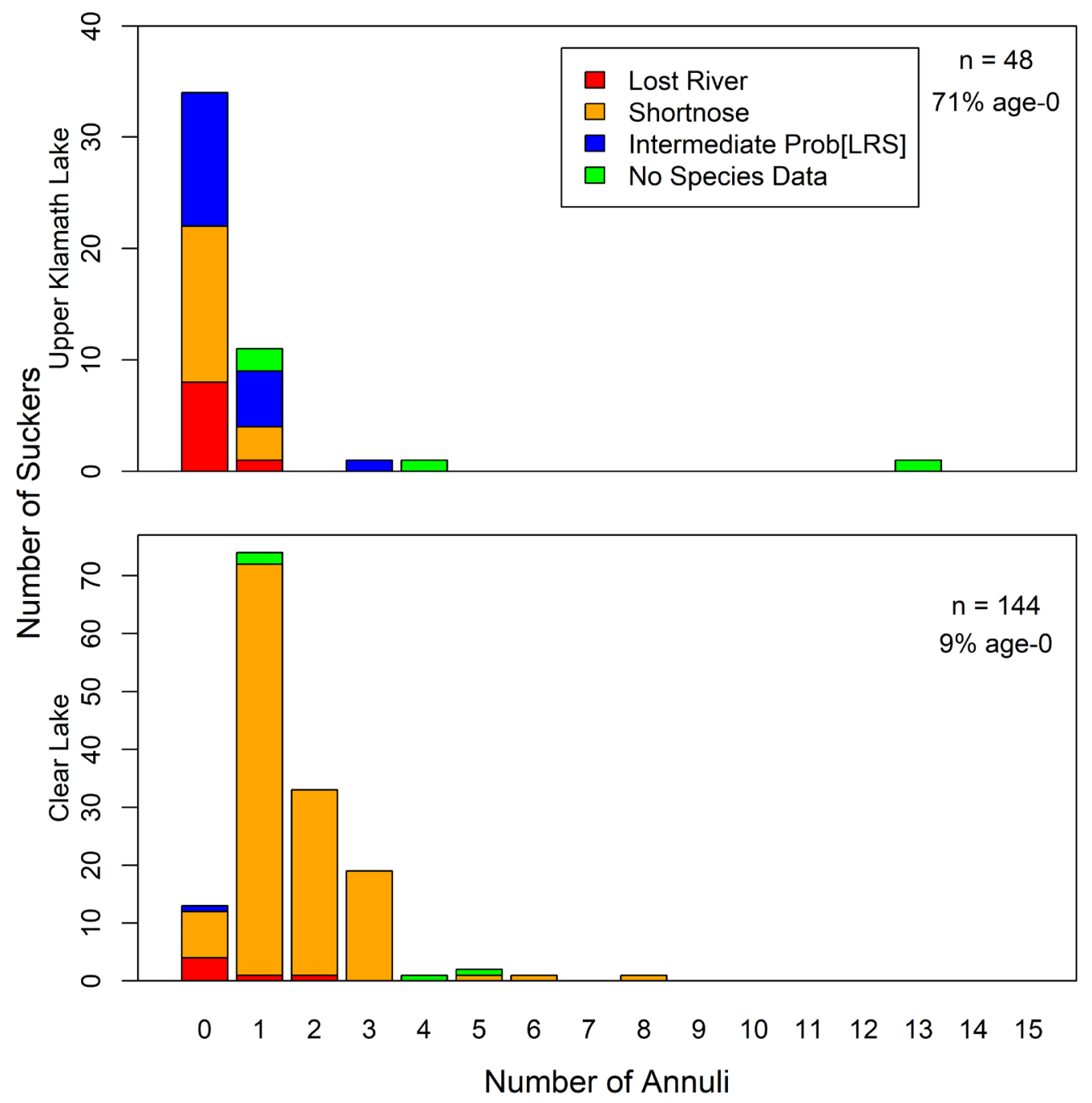

Figure 3. Graphs showing number of annuli on suckers collected at Upper Klamath Lake, Oregon and Clear Lake, California, 2017. Taxa were identified as the probability of STRUCTURE assignment LRS (Prob[LRS]). Fish with Prob[LRS] $\leq 0.05$ are called shortnose suckers, fish with Prob[LRS] $\geq 0.95$ are called Lost River sucker, and fish with $0.05<\operatorname{Prob}[L R S]<0.95$ are called Intermediate Prob [LRS]. The percentage of the total number $(n)$ of suckers in each plot that had no annuli on fin rays (age-0) are given. 


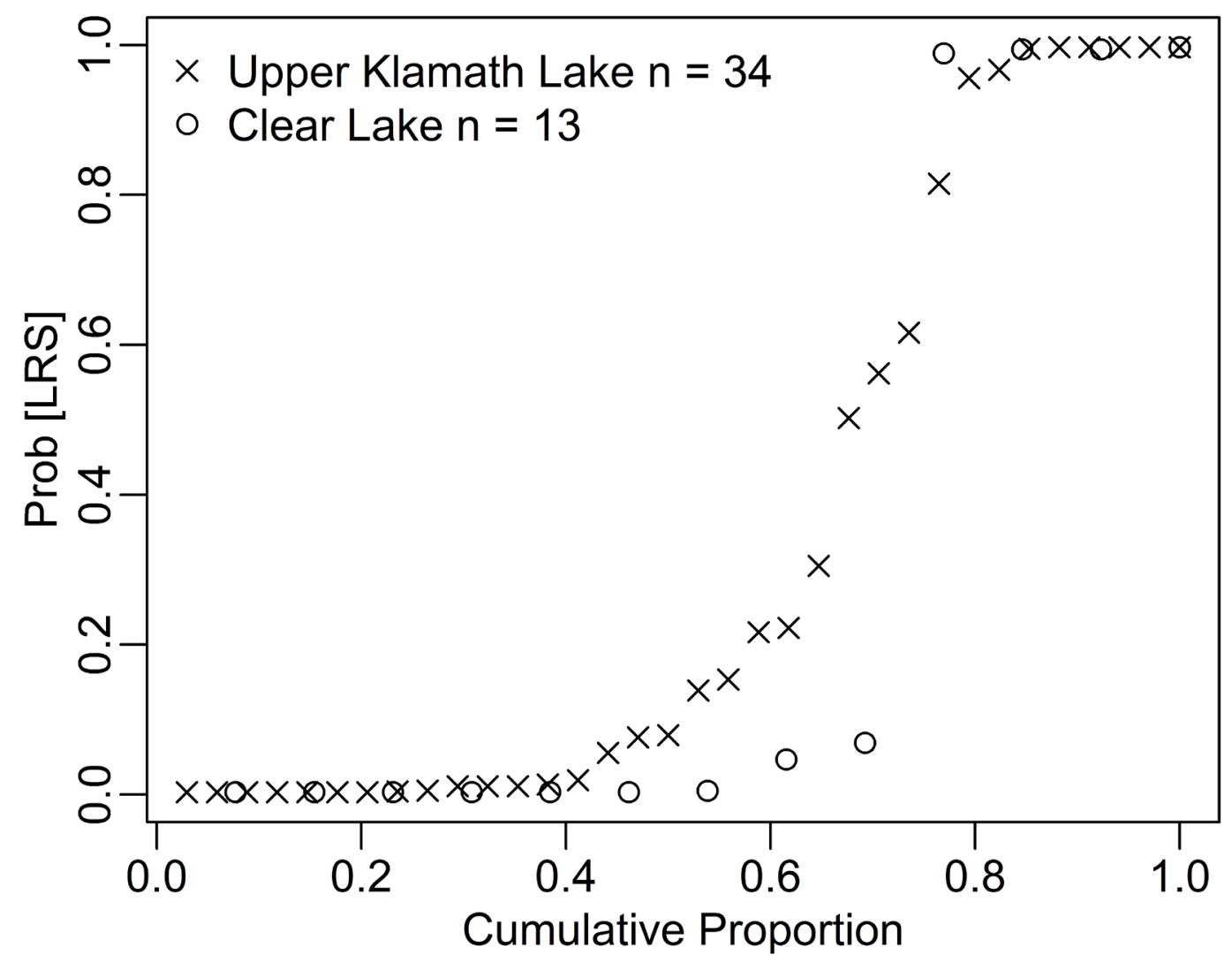

Figure 4. Probability of taxa assignment as Lost River Sucker based on STRUCTURE (Prob[LRS]) at fixed sites in Upper Klamath Lake, Oregon, and Clear Lake, California, 2017. The numbers of age-0 fish sampled from each lake (n) are given. 


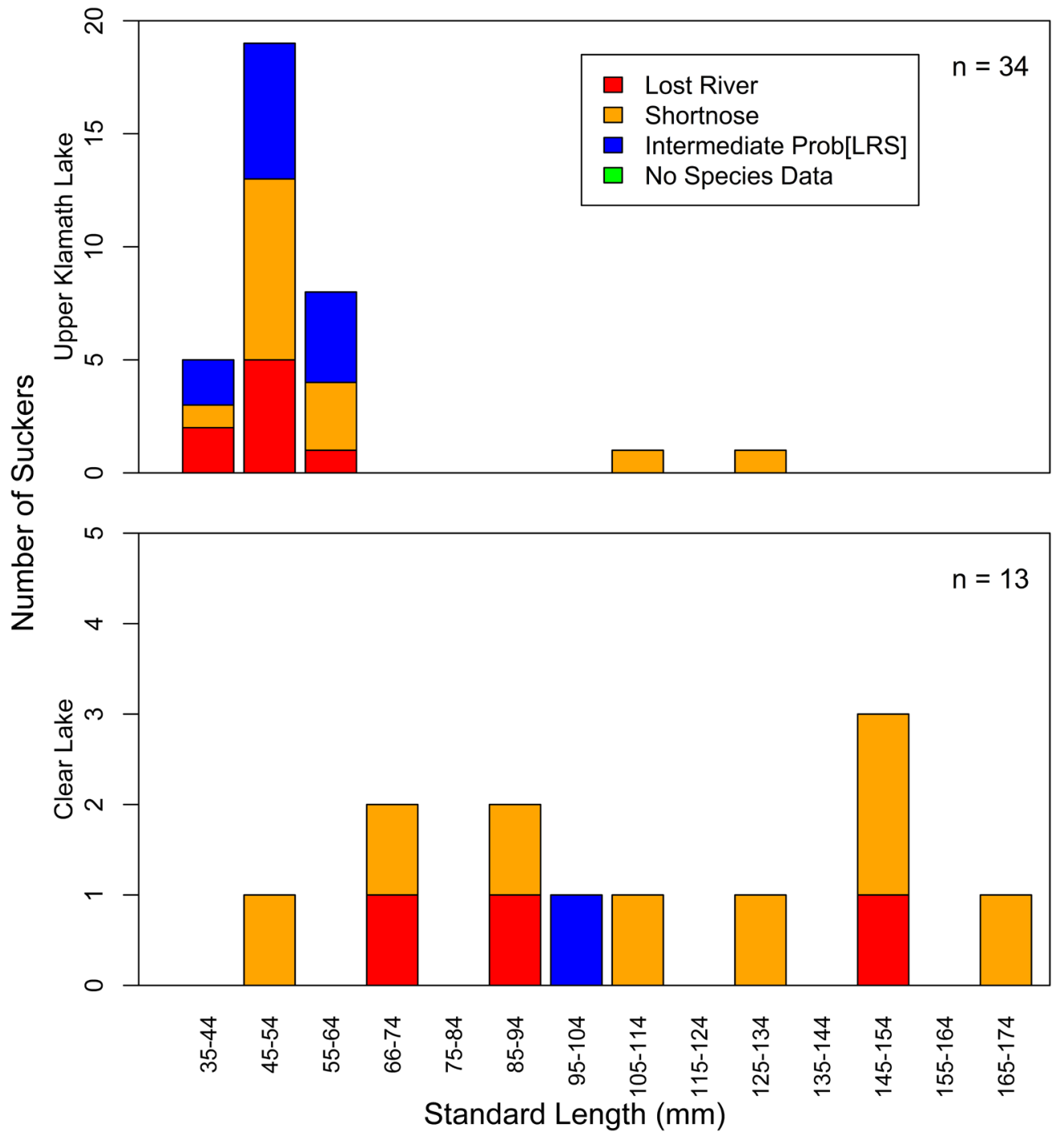

Figure 5. Graphs showing standard lengths of age- 0 suckers collected at fixed locations in Upper Klamath Lake, Oregon, and Clear Lake, California. Taxa were identified as the probability of STRUCTURE assignment LRS (Prob[LRS]). Fish with Prob[LRS] $\leq 0.05$ are called shortnose suckers, fish with Prob[LRS] $\geq 0.95$ are called Lost River sucker, and fish with $0.05<\operatorname{Prob}[L R S]<0.95$ are called Intermediate Prob [LRS]. The number of fish in each panel are given (n). 
Table 4. Catch per unit effort and percent of age-0 suckers for each taxa captured in Upper Klamath Lake, Oregon, and Clear Lake, California, in 2017.

[The number of total and age- 0 suckers captured in each taxa, the catch per unit effort (CPUE), and the percentage of each taxa that were age-0 are given. Taxa were identified based their genetic information from STRUCTURE results.]

\begin{tabular}{lcccc|rrrr}
\hline & \multicolumn{4}{c}{ Upper Klamath Lake } & \multicolumn{3}{c}{ Clear Lake } \\
\cline { 2 - 9 } \multicolumn{1}{c}{ Taxa } & $\begin{array}{c}\text { Number } \\
\text { suckers }\end{array}$ & $\begin{array}{c}\text { Number } \\
\text { age-0 }\end{array}$ & $\begin{array}{c}\text { Age-0 } \\
\text { CPUE }\end{array}$ & $\begin{array}{c}\text { Age-0 } \\
\text { (percent) }\end{array}$ & $\begin{array}{r}\text { Number } \\
\text { suckers }\end{array}$ & $\begin{array}{c}\text { Number } \\
\text { age-0 }\end{array}$ & $\begin{array}{c}\text { Age-0 } \\
\text { CPUE }\end{array}$ & $\begin{array}{c}\text { Age-0 } \\
\text { (percent) }\end{array}$ \\
\hline Lost River Suckers & 9 & 8 & 0.03 & 89 & 6 & 4 & 0.02 & 67 \\
Shortnose Suckers & 17 & 14 & 0.05 & 82 & 137 & 8 & 0.04 & 6 \\
Intermediate Prob [LRS] & 18 & 12 & 0.05 & 67 & 1 & 1 & 0.01 & 100 \\
No Taxa Data & 4 & 0 & 0.00 & 0 & 4 & 0 & 0.00 & 0 \\
All Taxa Suckers & 48 & 34 & 0.13 & 71 & 148 & 13 & 0.09 & 9 \\
\hline
\end{tabular}

Table 5. Catch statistics for August age-0 suckers from Upper Klamath Lake, Oregon for 2015, 2016, and 2017.

[ $\mathrm{n}$ is the number of suckers. Total CPUE was calculated as the number of fish captured per net set.]

\begin{tabular}{llccc}
\hline & & $\begin{array}{c}\text { August } \\
\mathbf{2 0 1 5}\end{array}$ & $\begin{array}{c}\text { August } \\
\mathbf{2 0 1 6}\end{array}$ & $\begin{array}{c}\text { August } \\
\mathbf{2 0 1 7}\end{array}$ \\
\hline Number of nets & & 98 & 94 & 96 \\
\hline Lost River Suckers & $\mathrm{n}$ & 21 & 120 & 8 \\
& Total CPUE & 0.21 & 1.28 & 0.08 \\
Intermediate Prob [LRS] & $\mathrm{n}$ & 13 & 59 & 12 \\
& Total CPUE & 0.13 & 0.63 & 0.13 \\
Shortnose Suckers & $\mathrm{n}$ & 17 & 35 & 14 \\
& Total CPUE & 0.17 & 0.37 & 0.15 \\
Total Suckers & & 51 & 214 & 34 \\
& $\mathrm{n}$ & 0.52 & 2.28 & 0.35 \\
\hline
\end{tabular}

Table 6. August to September survival indices for age-0 suckers in each taxa captured in Upper Klamath Lake, Oregon.

[Survival indices were calculated as the catch per net in September divided by the catch per net in August.]

\begin{tabular}{llll}
\hline & $\mathbf{2 0 1 5}$ & $\mathbf{2 0 1 6}$ & $\mathbf{2 0 1 7}$ \\
\hline Lost River Suckers & 0.29 & 0.16 & 0.14 \\
Shortnose Suckers & NA & 0.35 & 0.00 \\
Total Suckers & 0.73 & 0.19 & 0.03 \\
\hline
\end{tabular}




\section{Table 7. Catch statistics for the 2016 cohort of suckers from Upper Klamath Lake, Oregon.}

[The percentage of nets to successfully capture one or more sucker in each taxa, mean and standard deviation (SD) catch per net (CPUE) in nets that successfully captured one or more sucker, and total suckers captured in all nets set (Total CPUE) are given for each seasonal sampling period. Because statistics are shown by year-class, fish captured in 2017 are age-1 in the table. Data collected in 2016 also are reported in Burdick and others (2018)]

\begin{tabular}{|c|c|c|c|c|c|c|}
\hline & & $\begin{array}{l}\text { August 8-12, } \\
2016\end{array}$ & $\begin{array}{c}\text { September 19-23, } \\
2016\end{array}$ & $\begin{array}{l}\text { June12-16, } \\
2017\end{array}$ & $\begin{array}{l}\text { August 7-11, } \\
2017\end{array}$ & $\begin{array}{c}\text { September 18-22, } \\
2017\end{array}$ \\
\hline Number of nets & & 94 & 80 & 80 & 96 & 88 \\
\hline \multirow[t]{3}{*}{ Lost River Suckers } & Percentage & 31 & 18 & 1 & 0 & 0 \\
\hline & Mean (SD) & $4.14(4.96)$ & $1.14(0.36)$ & $1.00(\mathrm{NA})$ & 0.00 (NA) & 0.00 (NA) \\
\hline & Total CPUE & 1.28 & 0.20 & 0.01 & 0.00 & 0.00 \\
\hline \multirow{4}{*}{$\begin{array}{l}\text { Intermediate Prob } \\
\text { [LRS] }\end{array}$} & & & & & & \\
\hline & Percentage & 29 & 8 & 4 & 0 & 2 \\
\hline & Mean (SD) & $2.18(1.98)$ & $1.33(0.52)$ & 1.00 (NA) & 0.00 (NA) & 1.00 (NA) \\
\hline & Total CPUE & 0.63 & 0.10 & 0.04 & 0.00 & 0.02 \\
\hline \multirow[t]{3}{*}{ Shortnose Suckers } & Percentage & 19 & 10 & 1 & 1 & 0 \\
\hline & Mean (SD) & 1.94 (1.59) & $1.25(0.71)$ & 2.00 (NA) & 1.00 (NA) & 0.00 (NA) \\
\hline & Total CPUE & 0.37 & 0.13 & 0.03 & 0.01 & 0.00 \\
\hline \multirow{3}{*}{ Total Suckers } & Percentage & 86 & 36 & 6 & 1 & 2 \\
\hline & Mean (SD) & $2.75(3.40)$ & $1.21(0.49)$ & $1.14(0.38)$ & 1.00 (NA) & 1.00 (NA) \\
\hline & Total CPUE & 2.28 & 0.44 & 0.10 & 0.01 & 0.02 \\
\hline
\end{tabular}




\section{Table 8. Catch statistics for the 2017 cohort of suckers from Upper Klamath Lake, Oregon.}

[The percentage of nets to successfully capture one or more sucker in each taxa, mean and standard deviation (SD) catch per net (CPUE) in nets that successfully captured one or more sucker, and total suckers captured in all nets set (Total CPUE) are given for each seasonal sampling period.]

\begin{tabular}{llcl}
\hline & & $\begin{array}{c}\text { August 7-11, } \\
\text { 2017 }\end{array}$ & $\begin{array}{c}\text { September 18-22, } \\
\text { 2017 }\end{array}$ \\
\hline Number of nets & 96 & 88 \\
\hline Lost River Suckers & Percentage & 6 & 1 \\
& Mean (SD) & $1.16(0.41)$ & 1.00 (NA) \\
& Total CPUE & 0.07 & 0.01 \\
Intermediate Prob [LRS] & Percentage & 13 & 0 \\
& Mean (SD) & $1.00(\mathrm{NA})$ & 0.00 (NA) \\
& Total CPUE & 0.13 & 0.00 \\
Shortnose Suckers & Percentage & 11 & 0 \\
& Mean (SD) & $1.27(0.46)$ & 0.00 (NA) \\
& Total CPUE & 0.15 & 0.00 \\
Total Suckers & & & 1 \\
& Percentage & 30 & 1.00 (NA) \\
& Mean (SD) & $1.14(0.35)$ & 0.01 \\
\hline
\end{tabular}




\section{Clear Lake Year-Class Strength and Survival}

The most abundant age class captured in Clear Lake in 2017 was age-1, followed by age-2 (fig. 3). Age- 0 suckers made 9 percent of the catch in Clear Lake. Age composition of suckers indicate greater survival past age-1 in Clear Lake than Upper Klamath Lake (fig. 3). Of the 13 age-0 suckers captured in Clear Lake in 2017, 4 were Lost River suckers, 8 were shortnose suckers, and 1 was an intermediate prob [LRS] (fig. 3, table 4). Age-1, age-2, and age-3 suckers were almost entirely comprised of shortnose suckers (fig. 3). Age-0 shortnose suckers were typically larger and less numerous in Clear Lake relative to Upper Klamath Lake (fig. 5).

From 2015 to 2017, overall CPUE from the first detection to the last detection increased for the 2015 cohort and decreased for the 2016 and 2017 cohorts (tables 9-11). A total of 19 age-3 suckers were captured in 2017, which was the first detection of the 2014 cohort in Clear Lake. The 2015 cohort in Clear Lake was not captured during the 2015 monitoring season, however from this cohort three individuals were captured during September 2016, one during June 2017, seven during August 2017 , and 25 during the September 2017 sampling periods (table 9). The fish caught from the 2015 cohort were primarily shortnose sucker with the exception of one Lost River sucker captured in August 2017 (table 9). The 2016 cohort was detected during the 2016 sampling season, but was primarily made up of shortnose sucker with Lost River sucker only making up a fraction of the catch (tables 10 and 12). Only one Lost River Sucker from the 2016 cohort was captured during the 2017 monitoring season. The 2016 cohort of shortnose suckers were more persistent by being detected throughout the 2016 and 2017 seasons. The 2017 cohort was detected during sampling, but catch rates for both species were relatively low (tables 11 and 12).

August and September CPUEs were variable and did not always decrease within years for cohorts in Clear Lake. CPUE for the 2016 cohort of Lost River and shortnose sucker increased between August and September. CPUE of the 2016 shortnose sucker cohort decreased between September of 2016 and June of 2017 but then increased between June and August of 2017. CPUE for the 2017 cohorts of both taxa were very low, and in the case of shortnose suckers, increased between August and September. 
Table 9. Catch statistics for the 2015 cohort of suckers from Clear Lake, California.

[The percentage of nets to successfully capture one or more sucker in each taxa, mean and standard deviation (SD) catch per net (CPUE) in nets that successfully captured one or more sucker, and total suckers captured in all nets set (Total CPUE) are given for each seasonal sampling period. CPUE was calculated as the number of fish per net set. Because statistics are shown by year-class, fish captured in 2016 are age-1 and in 2017 are age-2 in the table. No suckers of this cohort were captured in 2015].

\begin{tabular}{|c|c|c|c|c|c|c|c|c|c|}
\hline & & $\begin{array}{c}\text { August 3-7, } \\
2015 \\
\end{array}$ & $\begin{array}{c}\text { September 14-18, } \\
2015 \\
\end{array}$ & $\begin{array}{c}\text { June 6-10, } \\
2016 \\
\end{array}$ & $\begin{array}{l}\text { August 1-5, } \\
2016 \\
\end{array}$ & $\begin{array}{c}\text { September 12-16, } \\
2016 \\
\end{array}$ & $\begin{array}{c}\text { June 5-9, } \\
2017 \\
\end{array}$ & $\begin{array}{c}\text { August 14- } \\
18,2017 \\
\end{array}$ & $\begin{array}{c}\text { September 18-22, } \\
2017 \\
\end{array}$ \\
\hline Number of nets & & 70 & 70 & 70 & 70 & 70 & 70 & 70 & 70 \\
\hline \multirow[t]{3}{*}{ Lost River Suckers } & Percentage & 0 & 0 & 0 & 0 & 0 & 0 & 1 & 0 \\
\hline & Mean (SD) & 0.00 (NA) & 0.00 (NA) & 0.00 (NA) & 0.00 (NA) & 0.00 (NA) & 0.00 (NA) & 1.00 (NA) & 0.00 (NA) \\
\hline & Total CPUE & 0.00 & 0.00 & 0.00 & 0.00 & 0.00 & 0.00 & 0.01 & 0.00 \\
\hline \multicolumn{10}{|l|}{ Intermediate Prob } \\
\hline \multirow[t]{3}{*}{ [LRS] } & Percentage & 0 & 0 & 0 & 0 & 0 & 0 & 0 & 0 \\
\hline & Mean (SD) & 0.00 (NA) & 0.00 (NA) & 0.00 (NA) & 0.00 (NA) & 0.00 (NA) & 0.00 (NA) & 0.00 (NA) & 0.00 (NA) \\
\hline & Total CPUE & 0.00 & 0.00 & 0.00 & 0.00 & 0.00 & 0.00 & 0.00 & 0.00 \\
\hline \multirow[t]{3}{*}{ Shortnose Suckers } & Percentage & 0 & 0 & 0 & 0 & 4 & 1 & 7 & 12 \\
\hline & Mean (SD) & 0.00 (NA) & 0.00 (NA) & 0.00 (NA) & 0.00 (NA) & 1.00 (NA) & 1.00 (NA) & $1.2(0.45)$ & $2.78(3.27)$ \\
\hline & Total CPUE & 0.00 & 0.00 & 0.00 & 0.00 & 0.04 & 0.01 & 0.09 & 0.36 \\
\hline \multirow[t]{3}{*}{ Total Suckers } & Percentage & 0 & 0 & 0 & 0 & 4 & 1 & 8 & 12 \\
\hline & Mean (SD) & 0.00 (NA) & 0.00 (NA) & 0.00 (NA) & 0.00 (NA) & 1.00 (NA) & 1.00 (NA) & $1.17(0.41)$ & $2.78(3.27)$ \\
\hline & Total CPUE & 0.00 & 0.00 & 0.00 & 0.00 & 0.04 & 0.01 & 0.10 & 0.36 \\
\hline
\end{tabular}


Table 10. Catch statistics for the 2016 cohort of suckers from Clear Lake, California.

[The percentage of nets to successfully capture one or more sucker in each taxa, mean and standard deviation (SD) catch per net (CPUE) in nets that successfully captured one or more sucker, and total suckers captured in all nets set (Total CPUE) are given for each seasonal sampling period. Because statistics are shown by year-class, fish captured in 2017 are age-1 in the table. Total CPUE was calculated as number of suckers captured divided by the number of nets set].

\begin{tabular}{|c|c|c|c|c|c|c|}
\hline & & $\begin{array}{c}\text { August 1-5, } \\
2016\end{array}$ & $\begin{array}{c}\text { September 12-16, } \\
2016 \\
\end{array}$ & $\begin{array}{c}\text { June 5-9, } \\
2017 \\
\end{array}$ & $\begin{array}{c}\text { August 14-18, } \\
2017\end{array}$ & $\begin{array}{c}\text { September 18-22, } \\
2017 \\
\end{array}$ \\
\hline Number of nets & & 70 & 70 & 70 & 70 & 70 \\
\hline \multirow[t]{3}{*}{ Lost River Suckers } & Percentage & 3 & 7 & 0 & 1 & 0 \\
\hline & Mean (SD) & 1.00 (NA) & $1.60(1.34)$ & 0.00 (NA) & 1.00 (NA) & 0.00 (NA) \\
\hline & Total CPUE & 0.03 & 0.11 & 0.00 & 0.01 & 0.00 \\
\hline \multicolumn{7}{|l|}{ Intermediate Prob } \\
\hline \multirow[t]{3}{*}[\mathrm{LRS}]{} & Percentage & 1 & 1 & 0 & 0 & 0 \\
\hline & Mean (SD) & 1.00 (NA) & 1.00 (NA) & 0.00 (NA) & 0.00 (NA) & 0.00 (NA) \\
\hline & Total CPUE & 0.01 & 0.01 & 0.00 & 0.00 & 0.00 \\
\hline \multirow[t]{3}{*}{ Shortnose Suckers } & Percentage & 16 & 54 & 4 & 37 & 19 \\
\hline & Mean (SD) & $1.91(1.45)$ & $3.05(4.92)$ & 1.00 (NA) & $1.76(1.21)$ & $1.69(1.11)$ \\
\hline & Total CPUE & 0.30 & 1.66 & 0.04 & 0.66 & 0.20 \\
\hline \multirow[t]{3}{*}{ Total Suckers } & Percentage & 20 & 69 & 4 & 39 & 19 \\
\hline & Mean (SD) & $1.71(1.32)$ & $3.38(6.11)$ & 1.00 (NA) & $1.74(1.20)$ & $1.69(1.11)$ \\
\hline & Total CPUE & 0.34 & 2.31 & 0.04 & 0.67 & 0.20 \\
\hline
\end{tabular}


Table 11. Catch statistics for the 2017 cohort of suckers from Clear Lake, California.

[The percentage of nets to successfully capture one or more sucker in each taxa, mean and standard deviation (SD) catch per net (CPUE) in nets that successfully captured one or more sucker, and total suckers captured in all nets set (Total CPUE) are given for each seasonal sampling period. Total CPUE was calculated as number of suckers captured divided by the number of nets set.]

\begin{tabular}{llcl}
\hline & \multicolumn{1}{c}{$\begin{array}{c}\text { August 7-11, } \\
\mathbf{2 0 1 7}\end{array}$} & $\begin{array}{c}\text { September 18-22, } \\
\mathbf{2 0 1 7}\end{array}$ \\
\hline Number of nets & & 70 & 70 \\
\hline Lost River Suckers & Percentage & 3 & 0 \\
& Mean (SD) & $2.00(1.41)$ & 0.00 (NA) \\
& Total CPUE & 0.06 & 0.00 \\
Intermediate Prob & & & \\
[LRS] & Percentage & 1 & 1 \\
& Mean (SD) & 1.00 (NA) & 1.00 (NA) \\
& Total CPUE & 0.01 & 0.01 \\
Shortnose Suckers & Percentage & 11 & 6 \\
& Mean (SD) & $1.00(\mathrm{NA})$ & 1.00 (NA) \\
& Total CPUE & 0.16 & 0.06 \\
Total Suckers & & & 6 \\
& Percentage & 16 & 1.00 (NA) \\
& Mean (SD) & $1.40(0.89)$ & 0.07 \\
\hline
\end{tabular}


Table 12. Catch statistics for August age-0 suckers from Clear Lake, California for 2015, 2016, and 2017.

[ $\mathrm{n}$ is the number of suckers. Total CPUE was calculated as number of suckers captured divided by the number of nets set.]

\begin{tabular}{lllcc}
\hline & & $\begin{array}{c}\text { August } \\
\mathbf{2 0 1 5}\end{array}$ & $\begin{array}{c}\text { August } \\
\mathbf{2 0 1 6}\end{array}$ & $\begin{array}{c}\text { August } \\
\mathbf{2 0 1 7}\end{array}$ \\
\hline Number of nets & & 70 & 70 & 70 \\
\hline Lost River Suckers & $\mathrm{n}$ & 0 & 2 & 4 \\
& Total CPUE & 0.00 & 0.03 & 0.06 \\
Intermediate Prob [LRS] & $\mathrm{n}$ & 0 & 1 & 1 \\
& Total CPUE & 0.00 & 0.01 & 0.01 \\
Shortnose Suckers & $\mathrm{n}$ & 0 & 21 & 8 \\
& Total CPUE & 0.00 & 0.30 & 0.11 \\
Total Suckers & & & & \\
& $\mathrm{n}$ & 0 & 24 & 13 \\
& Total CPUE & 0.00 & 0.34 & 0.19 \\
\hline
\end{tabular}

\section{Length and Apparent Growth of Clear Lake Shortnose Suckers}

The 2016 cohort of shortnose suckers in Clear Lake appeared to grow between August and September and between 2016 and 2017 (fig. 6). Growth of this cohort between August and September of 2016 was previously reported (Burdick and others, 2018). As age-1 fish, the 2016 shortnose sucker cohort were on average 10.87 mm SL larger in September than August of 2017. The cohort was 81.15 $\mathrm{mm}$ SL longer on average in August of 2017 than August of 2016, and $66.50 \mathrm{~mm}$ SL longer in September of 2017 than September of 2016. 


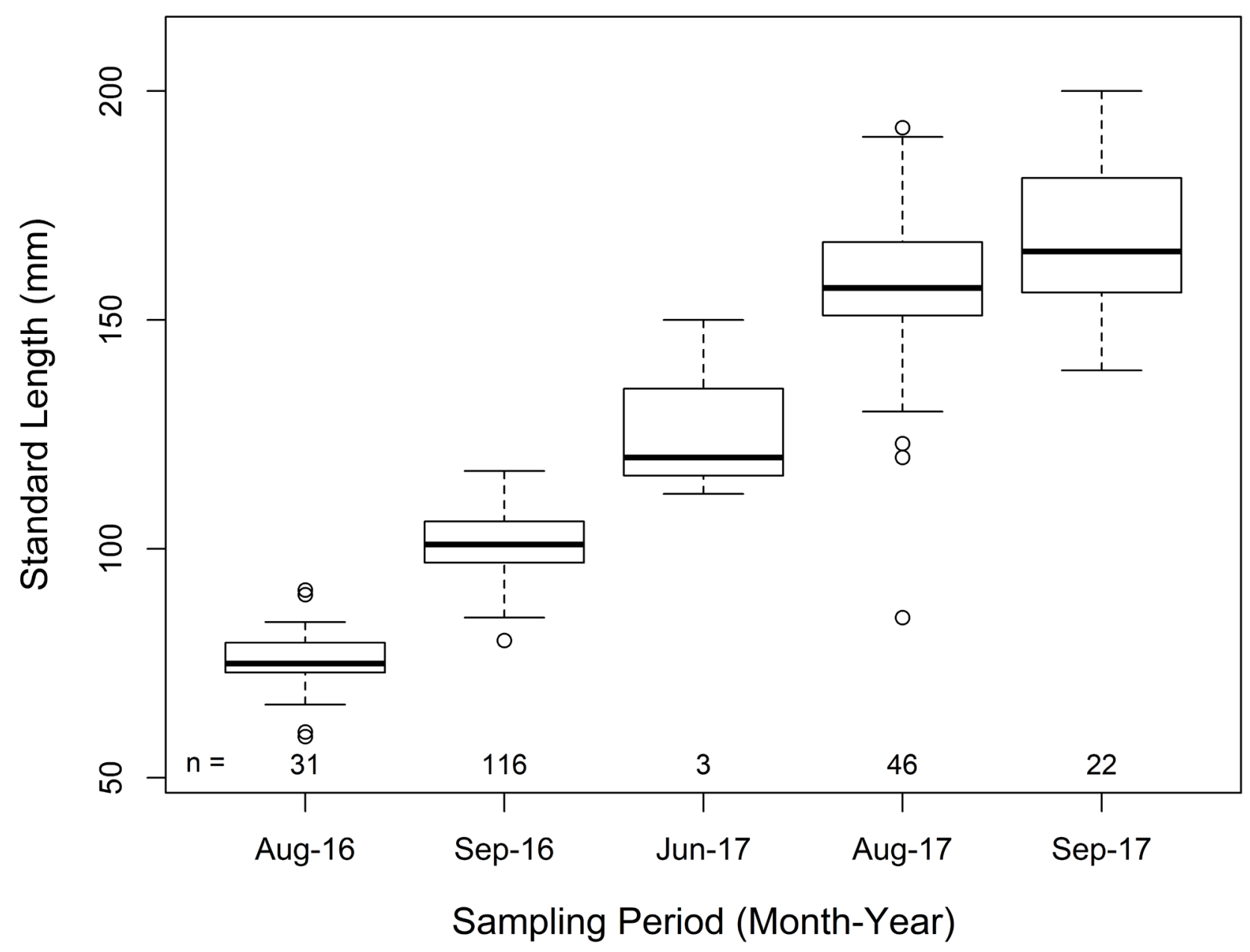

Figure 6. Standard length boxplot of the 2016 cohort of shortnose suckers from Clear Lake, California.

\section{Afflictions}

The four most common afflictions observed on suckers were more prevalent in Upper Klamath Lake than Clear Lake. Lernaea sp. were observed less on Clear Lake suckers than on Upper Klamath Lake suckers in all years (tables 13 and 14). Petechial hemorrhages of the skin were more common on age-0 suckers in Upper Klamath Lake than Clear Lake in 2016 and 2017 (table 15). Petechial hemorrhages of the skin also were observed on age-1 suckers from Upper Klamath Lake, but not from Clear Lake (table 16). Deformed opercula were observed only on age-0 suckers from Upper Klamath Lake (table 17). Lamprey wounds were uncommon overall, except on age-1 suckers from Upper Klamath Lake in 2017 (tables 18 and 19).

Among-year variation in affliction rates did not indicate years with better or worse overall sucker health. Lernaea sp. and petechial hemorrhages on the skin were slightly less prevalent in 2017 than in 2015 and 2016 on age-0 suckers from Upper Klamath Lake (tables 13 and 15). In contrast, opercular deformities and lamprey wounds increased slightly from 2015 to 2017 on age-0 suckers from Upper Klamath Lake (tables 17 and 18). The proportion of age-1 and older suckers with petechial hemorrhaging stayed the same from 2015 to 2017 in Upper Klamath Lake (table 16). The proportion of age-1 and older suckers in Upper Klamath Lake with lamprey wounds increased slightly from 2015 to 
2017. The only affliction to affect more than 5 percent of age- 1 and older suckers a year in Clear Lake was Lernaea sp., and it was most prevalent within this lake in 2015 (tables 13 and 14).

Observed afflictions occurred at low intensity. Lernaea sp. was the most common affliction recorded in 2017, but the intensity of parasitism was low. The maximum number of Lernaea sp. attached to a single sucker was six. If Lernaea sp. were observed on suckers, the fish most often had only one parasite. Most of the deformed opercula observations consisted of only one missing opercula, ; however, two fish collected in 2017 were observed with both opercula missing. Lamprey wounds occurred on no more than 1 percent of age- 0 suckers annually from Upper Klamath Lake (table 18); however, age-1 suckers from Upper Klamath Lake had more lamprey wounds than age-0 suckers (table 19). Black spot was observed only on age- 0 suckers and was most prevalent on the 2016 cohort in Upper Klamath Lake (table 20). Black spot was not observed on any Clear Lake suckers from 2015 through 2017 nor on any Upper Klamath Lake suckers in 2017.

Table 13. Proportions of age-0 suckers with attached Lernaea sp., Upper Klamath Lake, Oregon and Clear Lake, California, 2015, 2016 and 2017.

[Sample size of age-0 suckers captured given in parentheses. No age-0 suckers were captured in Clear Lake in 2015]

\begin{tabular}{lclccrc}
\hline \multicolumn{1}{c}{ Taxonomic Group } & UKL 2015 & CL 2015 & UKL 2016 & CL 2016 & UKL 2017 & \multicolumn{1}{c}{ CL 2017 } \\
\hline Lost River sucker & $0.79(24)$ & NA & $0.47(136)$ & $0.10(10)$ & $0.13(8)$ & $0.25(4)$ \\
Intermediate Prob[LRS] & $0.56(18)$ & NA & $0.33(67)$ & $0.00(2)$ & $0.33(12)$ & $0.00(1)$ \\
Shortnose sucker & $0.25(28)$ & NA & $0.22(45)$ & $0.04(137)$ & $0.21(14)$ & $0.13(8)$ \\
Total & $0.51(70)$ & NA & $0.38(258)$ & $0.04(186)$ & $0.26(34)$ & $0.16(13)$ \\
\hline
\end{tabular}

Table 14. Proportions of age-1 and older suckers with attached Lernaea sp., Upper Klamath Lake, Oregon and Clear Lake, California, 2015, 2016, and 2017.

[Number of age-1 and older suckers given in parentheses]

\begin{tabular}{lrcc}
\hline \multicolumn{1}{c}{ Lake } & $\mathbf{2 0 1 5}$ & $\mathbf{2 0 1 6}$ & $\mathbf{2 0 1 7}$ \\
\hline Upper Klamath Lake & $0.29(14)$ & $0.40(15)$ & $0.14(14)$ \\
Clear Lake & $0.17(24)$ & $0.06(65)$ & $0.05(131)$ \\
\hline
\end{tabular}

Table 15. Proportions of age- 0 suckers in each of the three taxa that had petechial hemorrhages on the skin in Upper Klamath Lake, Oregon, and Clear Lake, California, 2015, 2016 and 2017.

[Sample size of age-0 suckers given in parentheses. No age-0 suckers were captured in Clear Lake in 2015]

\begin{tabular}{lclllll}
\hline \multicolumn{1}{c}{ Taxonomic Group } & UKL 2015 & CL 2015 & UKL 2016 & CL 2016 & UKL 2017 & CL 2017 \\
\hline Lost River sucker & $0.38(24)$ & NA & $0.23(136)$ & $0.00(10)$ & $0.00(8)$ & $0.00(4)$ \\
Intermediate Prob[LRS] & $0.06(18)$ & NA & $0.16(67)$ & $0.00(2)$ & $0.08(12)$ & $0.00(1)$ \\
Shortnose sucker & $0.11(28)$ & NA & $0.13(45)$ & $0.01(137)$ & $0.14(14)$ & $0.00(8)$ \\
Total & $0.19(70)$ & NA & $0.19(258)$ & $0.01(186)$ & $0.09(34)$ & $0.00(13)$ \\
\hline
\end{tabular}


Table 16. Proportions of age-1 and older suckers with petechial hemorrhages of the skin in Upper Klamath Lake, Oregon, and Clear Lake, California, 2015, 2016, and 2017.

[Number of age-1 and older suckers given in parentheses]

\begin{tabular}{lrrr}
\hline \multicolumn{1}{c}{ Lake } & $\mathbf{2 0 1 5}$ & $\mathbf{2 0 1 6}$ & \multicolumn{1}{c}{$\mathbf{2 0 1 7}$} \\
\hline Upper Klamath Lake & $0.07(14)$ & $0.07(15)$ & $0.07(14)$ \\
Clear Lake & $0.00(24)$ & $0.00(65)$ & $0.00(131)$ \\
\hline
\end{tabular}

Table 17. Proportions of age- 0 suckers in each of the three taxa with deformed opercula in Upper Klamath Lake, Oregon, and Clear Lake, California, 2015, 2016 and 2017.

[Sample size of age-0 suckers given in parentheses. No age-0 suckers were captured in Clear Lake in 2015]

\begin{tabular}{lclllcl}
\hline \multicolumn{1}{c}{ Taxonomic Group } & UKL 2015 & CL 2015 & \multicolumn{1}{c}{ UKL 2016 } & \multicolumn{1}{c}{ CL 2016 } & UKL 2017 & \multicolumn{1}{c}{ CL 2017 } \\
\hline Lost River sucker & $0.04(24)$ & NA & $0.11(136)$ & $0.00(10)$ & $0.50(8)$ & $0.00(4)$ \\
Intermediate Prob[LRS] & $0.06(18)$ & NA & $0.12(67)$ & $0.00(2)$ & $0.08(12)$ & $0.00(1)$ \\
Shortnose sucker & $0.00(28)$ & NA & $0.02(45)$ & $0.00(137)$ & $0.07(14)$ & $0.00(8)$ \\
Total & $0.03(70)$ & NA & $0.10(258)$ & $0.00(186)$ & $0.18(34)$ & $0.00(13)$ \\
\hline
\end{tabular}

Table 18. Proportions of age-0 suckers in each of the three taxa with lamprey wounds in Upper Klamath Lake, Oregon, and Clear Lake, California, 2015, 2016 and 2017.

[Sample size of age-0 suckers given in parentheses. No age-0 suckers were captured in Clear Lake in 2015]

\begin{tabular}{lclllll}
\hline \multicolumn{1}{c}{ Taxonomic Group } & UKL 2015 & CL 2015 & \multicolumn{1}{c}{ UKL 2016 } & CL 2016 & UKL 2017 & CL 2017 \\
\hline Lost River sucker & $0.00(24)$ & NA & $0.02(136)$ & $0.00(10)$ & $0.00(8)$ & $0.00(4)$ \\
Intermediate Prob[LRS] & $0.00(18)$ & NA & $0.00(67)$ & $0.00(2)$ & $0.08(12)$ & $0.00(1)$ \\
Shortnose sucker & $0.00(28)$ & NA & $0.00(45)$ & $0.02(137)$ & $0.00(14)$ & $0.00(8)$ \\
Total & $0.00(70)$ & NA & $0.01(258)$ & $0.01(186)$ & $0.01(34)$ & $0.00(13)$ \\
\hline
\end{tabular}

Table 19. Proportions of age-1 and older suckers with lamprey wounds in Upper Klamath Lake, Oregon, and Clear Lake, California, 2015, 2016 and 2017.

[Sample size of age-1 and older suckers given in parentheses]

\begin{tabular}{lrcl}
\hline \multicolumn{1}{c}{ Lake } & $\mathbf{2 0 1 5}$ & $\mathbf{2 0 1 6}$ & \multicolumn{1}{c}{$\mathbf{2 0 1 7}$} \\
\hline Upper Klamath Lake & $0.00(14)$ & $0.07(15)$ & $0.25(14)$ \\
Clear Lake & $0.00(24)$ & $0.05(65)$ & $0.02(131)$ \\
\hline
\end{tabular}


Table 20. Proportions of age- 0 suckers in each of the three taxa with black spot in Upper Klamath Lake, Oregon and Clear Lake, California, 2015, 2016 and 2017.

[Sample size of age-0 suckers given in parentheses. No age-0 suckers were captured in Clear Lake in 2015]

\begin{tabular}{lclllll}
\hline \multicolumn{1}{c}{ Taxonomic Group } & UKL 2015 & CL 2015 & \multicolumn{1}{c}{ UKL 2016 } & CL 2016 & UKL 2017 & CL 2017 \\
\hline Lost River sucker & $0.00(24)$ & NA & $0.03(136)$ & $0.00(10)$ & $0.00(8)$ & $0.00(4)$ \\
Intermediate Prob[LRS] & $0.00(18)$ & NA & $0.04(67)$ & $0.00(2)$ & $0.00(12)$ & $0.00(1)$ \\
Shortnose sucker & $0.04(28)$ & NA & $0.11(45)$ & $0.00(137)$ & $0.00(14)$ & $0.00(8)$ \\
Total & $0.03(70)$ & NA & $0.05(258)$ & $0.00(186)$ & $0.00(34)$ & $0.00(13)$ \\
\hline
\end{tabular}

\section{Discussion}

\section{Upper Klamath Lake}

The annual August abundance of both taxa of age-0 suckers in Upper Klamath Lake has likely declined since the late 1990s and early 2000s (Burdick and Martin 2017). Due to inconsistencies in sampling locations and gear types used between our present monitoring program and previous efforts, we cannot quantitatively compare our age- 0 sucker CPUE to previous values using existing data. Within our three year monitoring effort, August abundance of age-0 suckers appeared greatest in 2016, but was likely low compared to historical abundances.

The timing of sampling, relative to when age-0 suckers grow large enough to be fully vulnerable to our gear ( $\sim 45 \mathrm{~mm} \mathrm{SL})$ and when they begin to disappear from catches, has the potential to bias indices of apparent relative year-class strength and survival. For example, peak catch rates occur around the first few weeks of August in Upper Klamath Lake in most years (for example, 2001-2007; Burdick and Martin, 2017). In other years, catch rates in Upper Klamath Lake increase throughout August (for example, 2009 and 2010; Burdick and Martin, 2017) or already appear to be declining at the beginning of August after sampling began (for example, 2003). There was some evidence that we missed the peak abundance of suckers of an exploitable size in 2017. From our gear-evaluation sampling in July that was not part of the standard annual monitoring in this report resulted in high catch rates of age- 0 suckers. Therefore, it is likely that more age- 0 suckers were produced and the rate of decline of age- 0 sucker abundance was greater than we had detected in our standardized monitoring.

With nearly no older juvenile suckers captured in Upper Klamath Lake, it is likely that the absence is attributed to mortality. Based on the majority of our catch in Clear Lake being age-1 or older suckers, we know that larger juvenile suckers are vulnerable to our trap nets and size selectivity is unlikely the reason for the absence of larger juveniles in Upper Klamath Lake. While some emigration has been recorded at the Link River Dam (Ellsworth and others, 2009), it does not explain the disappearance of entire cohorts. The primary evidence for the mortality of juvenile suckers in Upper Klamath Lake is the lack of recruitment to the adult populations (Hewitt and others, 2018). Without the balance of recruitment by new individuals to the spawning population, Lost River and shortnose suckers will continue on their downward trend until extirpation from Upper Klamath Lake.

While it is typical for survival to be very low in the early life stages of fish (Houde 1989), near complete disappearance of entire cohorts within the first two years is alarming. High fecundity may be a life-history strategy to overcome high mortality for suckers in the Klamath Basin, but near complete mortality is unsustainable (Rasmussen and Childress, 2018). Given the adult population has decreased more than 50 percent since the early 2000s (Hewitt and others, 2018), there would have to be a significant recruitment event soon for both species to recover naturally. 


\section{Clear Lake}

First detections of 2014 and 2015 cohorts of shortnose sucker, well after they were hatched appear to indicate that these suckers spent several years in the Willow Creek drainage before migrating to Clear Lake in the relatively wet years of 2016 and 2017. Willow Creek is the only known spawning location for Clear Lake suckers, with access available only when the lake surface elevation is $1,378.9 \mathrm{~m}$ $(4,524 \mathrm{ft})$ or greater (D. Hewitt oral communication, 2019). Willow Creek was inaccessible to spawning fish for all of the 2014 and 2015, half of the 2016, and most of the 2017 spawning seasons (fig. 7). Neither the 2014 or 2015 cohorts were detected in Clear Lake in 2015, leading Burdick and others (2018) to conclude that due to low water during the spawning season, cohorts of shortnose suckers were not produced in the Clear Lake drainage in 2014 or 2015. Then in 2016, three shortnose suckers from the 2015 cohort were detected in Clear Lake. In 2017, 19 shortnose suckers from the 2014 cohort and 32 from the 2015 cohort were captured in Clear Lake. Because lake-dwelling suckers did not have access to Willow Creek in 2014 and 2015, it seems likely that these cohorts were produced by adult stream-resident fish. Given our high sampling effort, rigorous aging methods, fairly large numbers of suckers in these age classes, and repeated detection of the 2015 cohort in two consecutive years, aging error is unlikely to explain the presence of the 2014 and 2015 cohorts. Nearly all the suckers captured from the 2014 and 2015 cohorts in Clear Lake were identified as shortnose sucker or Klamath largescale sucker based on 18 genetic SNPs and are equally likely to be either species. High flow events in 2016 and 2017 may have pushed suckers downstream from the refuge areas in Willow Creek to Clear Lake explaining the detection of the 2015 cohort in 2016 and the 2014 and 2015 cohorts in 2017. 


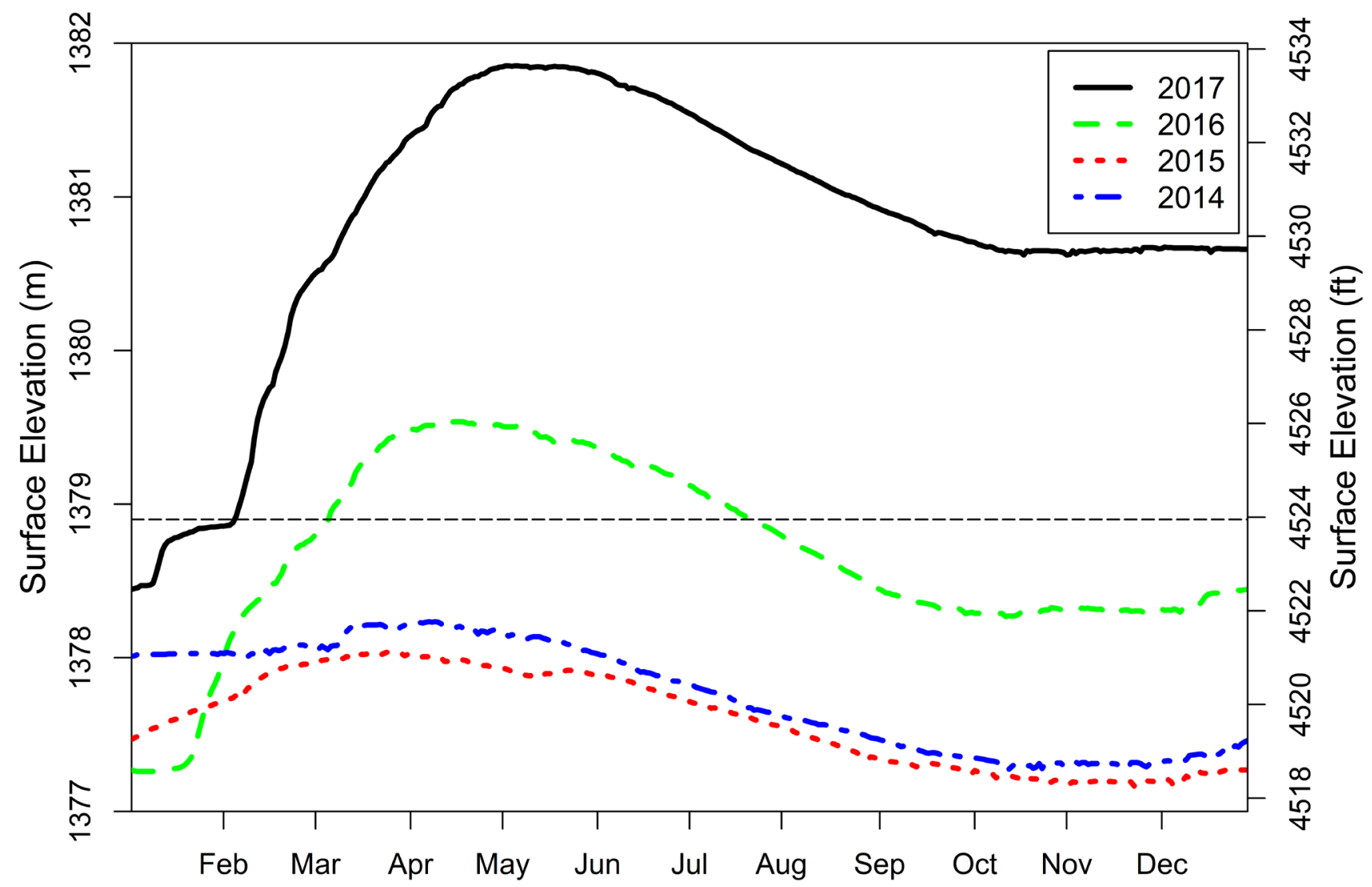

Figure 7. Lake surface elevations, Clear Lake Reservoir, California, 2014-17. The black horizontal dashed line represents the approximate elevation below which Willow Creek is not accessible to spawning adult suckers migrating from Clear Lake.

In Clear Lake, CPUE did not always decline between sampling periods within years as is expected for closed populations experiencing mortality and may indicate a combination of immigration and different sampling efficiency. CPUE increased between August and September for age-0 shortnose and Lost River suckers in 2016 and for age-0 shortnose suckers in 2017. Given that Clear Lake suckers spawn from February to April, it is unlikely that increases in August indicate newly spawned fish. Increases in CPUE between August and September may indicate that unlike Upper Klamath Lake populations, Clear Lake suckers have longer instream residence times after they hatch and are still immigrating to the lake in August or early September. Another possible explanation for increasing August to September CPUE is that due to the decrease in lake surface elevation, juveniles were concentrated in shallow water. Increasing efficiency as more fish grow to a size fully vulnerable to our gear (approximately $45 \mathrm{~mm} \mathrm{SL}$; Burdick and Martin, 2017); however, this seems like an unlikely explanation for increasing CPUE because most fish captured were well within the most vulnerable size range. Sampling efficiency in June of 2017 may have been reduced due to high water levels at the standard sites (averaged $3.72 \mathrm{~m}$ deep). To correct for this, the sampling protocol was changed in August 2017 to keep sampling depth consistent with previous years. 
We provide the first information on growth for shortnose suckers in Clear Lake, based on a relatively large sample size, following the 2016 cohort. The 2016 cohort of shortnose suckers in Clear Lake accumulated less length between August and September in 2017 at the age of 1 than they did during the same time period in 2016 as age- 0 fish. Based on the large variation in catches from previous years it is difficult to compare the growth of the 2016 cohort to prior years (Burdick, Hewitt, and others, 2015; Burdick and Rasmussen, 2013); however they do fall within the length range observed between 2010 and 2013 for age-1 fish collected in Clear Lake.

\section{Afflictions}

Lernaea sp. parasitism was one of the most common afflictions noted on suckers captured in either lake. Burdick, Elliott, and others (2015) observed that inflammation associated with Lernaea sp. attached to suckers was most often limited to a focal area in the skin and skeletal muscle directly surrounding the attachment site. They also reported focal inflammation and necrosis in the pancreas and intrapancreatic tissue adjacent to the spleen that was associated with a Lernaea sp. attachment site in one Lost River sucker captured from Upper Klamath Lake in 2015. The prevalence of Lernaea sp. observed in 2017 in both lakes was similar to that reported for Upper Klamath Lake from 2007 to 2015 (5-21 percent; Burdick, Wilkens, and VanderKooi, 2008; Burdick and Brown, 2010; Bottcher and Burdick, 2010; Burdick and VanderKooi, 2010; Burdick and Hewitt, 2012).

Petechial hemorrhaging was observed on several suckers, although the cause was not completely clear. Petechial hemorrhages of the skin have been common in Upper Klamath Lake since monitoring for them began in 2014 (Burdick, Elliott, and others, 2015). The very low prevalence of observed hemorrhages in Clear Lake relative to Upper Klamath Lake indicates that abrasions due to our method of capture were unlikely to be the primary cause of the hemorrhages. Burdick and others (2018) examined the hemorrhages microscopically and did not observe associated bacterial disease or other parasites. Janik and others (2018) observed petechial hemorrhaging on collected fish from Upper Klamath Lake canals, however they could not observe it by histology indicating that the infection was likely confined to the skin. Although petechial hemorrhaging was only found in Upper Klamath Lake, at this point there is no direct evidence that it is a cause of mortality.

Similar to previous sampling efforts by Burdick and others (2018), deformed opercula were observed only on juvenile suckers in Upper Klamath Lake. Deformed opercula were only observed on age-0 fish. With deformed or missing opercula, gills are more vulnerable to parasitism, poor water quality, and oxygen deficiencies ultimately increasing the risk of mortality. With no observations on age- 1 and older fish and deformed opercula presumed to be a permeant affliction, it is likely that missing or deformed opercula are highly associated with mortality. The exact cause of deformed opercula in Upper Klamath Lake is difficult to determine but potential explanations could be inbreeding, hybridization (Winemiller and Tayler, 1982; Tringali and others, 2001), nutrient deficiency (Chávez de Martínez, 1990; Lall, 2002), heavy metals, pesticides, or high egg incubation temperature (Boglione and others, 2013).

Lamprey wounds were observed on a small proportion of age- 0 suckers and a higher proportion of age- 1 and older fish. Older suckers are potentially more vulnerable to lamprey since there is more surface area on larger suckers for them to attach themselves. Several species of lamprey are native to the Upper Klamath Basin (Kostow, 2002), some of which are endemic. Given that lamprey have coevolved with suckers in the Klamath Basin, it is unlikely that they are the primary cause of annual juvenile sucker year-class failure. 
Black spot was observed only on age-0 suckers from Upper Klamath Lake. It was hypothesized that black spot caused by trematodes was associated with mortality of juvenile suckers (Markle and others, 2014). The intensity of black spot within the body of individual suckers was difficult to identify without causing mortality to the individual. Since black spot was observed on a relatively low proportion of fish we find it unlikely that it is a significant contributor to juvenile sucker mortality in Upper Klamath Lake, especially due to no observations of it in 2017. Differences in black spot between Clear Lake and Upper Klamath Lake are likely associated with the life cycle of the trematode that cause it to be more prevalent in Upper Klamath Lake.

\section{Conclusions}

The juvenile monitoring program has helped to describe sucker population dynamics in Upper Klamath Lake and Clear Lake, but the causes of high apparent first year sucker mortality in Upper Klamath Lake remain unclear. Upper Klamath Lake sucker populations are limited by first year apparent survival (Burdick and Martin, 2017). Differences in the prevalence of afflictions between lakes may offer clues, but more research is required to determine the causes of low sucker survival in Upper Klamath Lake. Determining the primary cause of the taxa specific differences in apparent mortality could not only change how Lost River suckers are managed, but might also offer additional clues as to the cause of age- 0 sucker mortality in Upper Klamath Lake. Many questions remain about the contributions of Willow Creek suckers to lake populations in the Clear Lake basin. Clear Lake suckers may out migrate from spawning tributaries much slower than in the Upper Klamath subbasin. Fish we call shortnose suckers in Clear Lake may have life history traits similar to the non-endangered Klamath large scale sucker, or may in fact be Klamath large scale sucker. Stream-resident populations of shortnose suckers may provide resiliency for Clear Lake suckers during dry years. Rasmussen and Childress (2018) estimated some Lost River and shortnose sucker populations may become extirpated within the next 50 years, which is an optimistic estimate. With adult populations diminishing, it has become more important than ever to determine the causes of recruitment failure of Lost River and shortnose suckers.

\section{Acknowledgements}

We thank the numerous personnel from the USGS Klamath Falls Field Station for assistance with collecting and processing the juvenile field data. We thank Barbara Martin and George Weekly for reviewing drafts of this report. Funding was provided by the Bureau of Reclamation, U.S. Department of Interior.

\section{References Cited}

Berry, C.R., Jr., Babey, G.J., and Shrader, T, 1991, Effect of Lernaea cyprinacea (Crustacea: Copepoda) on stocked rainbow trout (Oncorhynchus mykiss): Journal of Wildlife Diseases, v. 27, p. 206-213.

Boglione, C., Gisbert, E., Gavaia, P., Witten, P.E., Moren, M., Fontagne, S., and Koumoundours, G., 2013, Skeletal anomalies in reared European fish larvae and juveniles-Part 2, Main typologies, occurrences and causative factors: Reviews in Aquaculture, v. 5, no. 1, p. S121-S167.

Bottcher, J.L., and Burdick, S.M., 2010, Temporal and spatial distribution of endangered juvenile Lost River and Shortnose Suckers in relation to environmental variables in Upper Klamath Lake, Oregon-2009 annual data summary: U.S. Geological Survey Open-File Report 2010-1261, 42 p. 
Buettner, M. E., and Scoppettone, G. G., 1991, Distribution and information of the taxonomic status of the shortnose sucker (Chasmistes brevirostris) and Lost River suckers (Deltistes luxatus) in the Klamath River Basin, California: Seattle National Fishery Research Center, Reno, Nevada, 34 p.

Burdick, S.M., Anderson, G.O., and VanderKooi, S.P., 2009, Spring and summer spatial distribution of endangered juvenile Lost River and shortnose suckers in relation to environmental variables in Upper Klamath Lake, Oregon—2007 Annual Report: U.S. Geological Survey Open-File Report 2009-1043, $56 \mathrm{p}$.

Burdick, S.M., and Brown, D.T., 2010, Distribution and condition of larval and juvenile Lost River and shortnose suckers in the Williamson River Delta restoration project and Upper Klamath Lake, Oregon—2009 annual data summary: U.S. Geological Survey Open-File Report 2010-1216, 78 p.

Burdick, S.M., Elliott, D.G., Ostberg, C.O., Conway, C.M., Dolan-Caret, A., Hoy, M.S., Feltz, K.P., and Echols, K.R., 2015, Health and condition of endangered juvenile Lost River and shortnose suckers relative to water quality and fish assemblages in Upper Klamath Lake, Oregon, and Clear Lake Reservoir, California: U.S. Geological Survey Open-File Report 2015-1217, 56 p., http://dx.doi.org/10.3133/ofr20151217.

Burdick, S.M., and Hewitt, D.A., 2012, Distribution and condition of young-of-year Lost River and shortnose suckers in the Williamson River Delta restoration project and Upper Klamath Lake, Oregon, 2008-10-Final Report: U.S. Geological Survey Open-File Report 2012-1098, 52 p.

Burdick, S.M., Hewitt, D.A., Rasmussen, J.E., Hayes, B.S., Janney, E.C., and Harris, A.C., 2015, Effects of lake surface elevation on shoreline-spawning Lost River Suckers: North American Journal of Fisheries Management, v. 35, p. 478-490.

Burdick, S.M., and Martin, B.A., 2017, Inter-annual variability in apparent relative production, survival, and growth of juvenile Lost River and shortnose suckers in Upper Klamath Lake, Oregon, 2001-15: U.S. Geological Survey Open-File Report 2017-1069, 55 p., https://doi.org/10.3133/ofr20171069.

Burdick, S.M., Ostberg, C.O., Hereford, M.E., and Hoy, M.S., 2016, Juvenile sucker cohort tracking data summary and assessment of monitoring program, 2015: U.S. Geological Survey Open-File Report 2016-1164, 30 p., http://dx.doi.org/10.3133/ofr20161164.

Burdick, S.M., Ostberg, C.O., and Hoy, M.S., 2018, Juvenile Lost River and shortnose sucker year class strength, survival, and growth in Upper Klamath Lake, Oregon, and Clear Lake Reservoir, California-2016 Monitoring Report: U.S. Geological Survey Open-File Report 2018-1066, 43 p., https://doi.org/10.3133/ofr20181066.

Burdick, S.M., and Rasmussen, J., 2012, Preliminary juvenile Lost River and Shortnose Sucker investigations in Clear Lake, California-2011 pilot study summary: U.S. Geological Survey OpenFile Report 2012-1180, 18 p.

Burdick, S.M., and Rasmussen, J., 2013, Age and condition of juvenile catostomids in Clear Lake Reservoir, California: U.S. Geological Survey Open-File Report 2013-1188, 20 p.

Burdick, S.M, and Vanderkooi, S.P., 2010, Temporal and spatial distribution of endangered juvenile Lost River and shortnose suckers in relation to environmental variables in Upper Klamath Lake, Oregon—2008 annual data summary: U.S. Geological Survey Open-File Report 2010-1051, 36 p.

Burdick, S.M., Wilkens, A.X., and VanderKooi, S.P., 2008, Near-shore and off-shore habitat use by endangered juvenile Lost River and shortnose suckers in Upper Klamath Lake, Oregon—2006 data summary: U.S. Geological Survey Open-File Report 2007-1356, 30 p.

Chávez de Martínez, M.C., 1990, Vitamin C requirements of the Mexican native cichlid Cichlasoma urophthalmus (Gunther): Aquaculture (Amsterdam, Netherlands), v. 86, p. 409-416. 
Cooperman, M., and Markle, D.F., 2003, Rapid out-migration of Lost River and shortnose sucker larvae from in-river spawning beds to in-lake rearing grounds: Transactions of the American Fisheries Society, v. 132, p. 1,138-1,153.

Eldridge, D.B., Caldwell Eldridge, S.L., Schenk, L.N., Tanner, D.Q., and Wood, T.M., 2012, Waterquality data from Upper Klamath and Agency Lakes, Oregon, 2009-10: U.S. Geological Survey Open-File Report 2012-1142, 32 p.

Eldridge, S.L.C., Wood, T.M., and Echols, K.R., 2012, Spatial and temporal dynamics of cyanotoxins and their relation to other water quality variables in Upper Klamath Lake, Oregon, 2007-09: U.S. Geological Survey Scientific Investigations Report 2012-5069, 34 p.

Ellsworth, C.M., Torrey, T.J., and Vanderkooi, S.P., 2009, Patterns of larval sucker emigration from the Sprague and lower Williamson Rivers of the Upper Klamath Basin, Oregon, prior to the removal of Chiloquin dam- 2006 annual report: U.S. Geological Survey Open-File Report 2009-1027, 32 p.

Evanno, G., Regnaut, S., and Goudet, J., 2005, Detecting the number of clusters of individuals using the software STRUCTURE-A simulation study: Molecular Ecology, v. 14, p. 2611-2620.

Ferguson, J.A., Koketsu, W., Ninomiya, I., Rossignol, P.A., Jacobson, K.C., and Kent, M.L., 2011, Mortality of coho salmon (Oncorhynchus kisutch) associated with burdens of multiple parasite species: International Journal for Parasitology, v. 41, no. 9, p. 1197-1205.

Hendrixson, H.A., Burdick, S.M. VanderKooi, S.P., and Wilkens, A.X., 2007, Near-shore and off-shore habitat use by endangered, juvenile Lost River and shortnose suckers, and near-shore water quality, in Upper Klamath Lake, Oregon-Annual report 2004: Report of U.S. Geological Survey, Western Fisheries Research Center, Klamath Falls Field Station to the Bureau of Reclamation, Mid-Pacific Region, Klamath Falls, Oregon.

Hewitt, D.A., and Hayes, B.S., 2013, Monitoring of adult Lost River and shortnose suckers in Clear Lake Reservoir, California, 2008-2010: U.S. Geological Survey Open-File Report 2013-1301, 18 p., http://dx.doi.org/10.3133/ofr20131301.

Hewitt, D.A., Janney, E.C., Hayes, B.S., and Harris, A.C., 2015, Status and trends of adult Lost River (Deltistes luxatus) and shortnose (Chasmistes brevirostris) sucker populations in Upper Klamath Lake, Oregon, 2014: U.S. Geological Survey Open-File Report 2015-1189, 36 p., http://dx.doi.org/10.3133/ofr20151189.

Hewitt, D.A., Janney, E.C., Hayes, B.S., and Harris, A.C., 2018, Status and trends of adult Lost River (Deltistes luxatus) and shortnose (Chasmistes brevirostris) sucker populations in Upper Klamath Lake, Oregon, 2017: U.S. Geological Survey Open-File Report 2018-1064, 31 p., https://doi.org/10.3133/ofr20181064.

Houde, E. D., 1989, Subtleties and episodes in the early life of fishes: Journal of Fish Biology, v 35 p. 29-38.

Hoy, M.S., and Ostberg, C.O., 2015, Development of 20 TaqMan assays differentiating the endangered shortnose and Lost River suckers: Conservation Genetics Resources, v. 7, no. 3, p. 673-676, doi: 10.1007/s12686-015-0474-y.

Janik, A.J., Markle, D.F., Heidel, J.R., Kent, M.L., 2018, Histopathology and external examination of heavily parasitized Lost River Sucker Deltistes luxatus (Cope 1879) and Shortnose Sucker Chasmistes brevirostris (Cope 1879) from Upper Klamath Lake, Oregon: Journal of Fish Diseases, v. 41, p. 1675-1687.

Janney, E.C., Shively, R.S., Hayes, B.S., Barry, P.M., Perkins, D., 2008, Demographic analysis of Lost River sucker and shortnose sucker populations in Upper Klamath Lake, Oregon: Transactions of the American Fisheries Society, v 137 p. 1812-1825. 
Kostow, K., 2002, Oregon Lampreys: Natural History Status and Analysis of Management Issues:

Oregon Department of Fish and Wildlife Information Report 2002-01, 83 p., https://www.dfw.state.or.us/fish/species/docs/lampreys2.pdf

Lall, S.P., 2002, The minerals, in Halver, J.E., and Hardy, R.W., Fish nutrition (3d ed.): San Francisco, Academic Press, p. 259-308.

Markle, D.F., and Cooperman, M.S., 2002, Lost River and shortnose sucker biology and management of Upper Klamath Lake, in Braunworth, W.S., Jr., Welch, T., and Hathaway, R., Water allocation in the Klamath Reclamation Project, 2001-An assessment of natural resource, economic, social, and institutional issues with a focus on the Upper Klamath Basin: Corvallis, Oregon State University, p. 93-117.

Markle, D.F., Terwilliger, M.R., and Simon, D.C., 2014, Estimates of daily mortality from Neascus trematode in age-0 Shortnose Sucker (Chasmistes brevirostris) and the potential impact of avian predation: Environmental Biology of Fish, v. 97,p. 197-207.

National Marine Fisheries Service and U.S. Fish and Wildlife Service, 2013, Biological Opinions on the Effects of Proposed Klamath Project Operations, from May 31, 2013 through March 31, 2023, on Five Federally Listed Threatened and Endangered Species: Fish and Wildlife Service, Pacific Southwest Region, Sacramento, California. 607 p.

National Research Council, 2004, Endangered and threatened fishes in the Klamath River BasinCauses of decline and strategies for recovery: Washington, D.C., The National Academies Press, 398 .

Pritchard, J.K., Stephens, M., and Donnelly, P., 2000, Inference of population structure using multilocus genotype data: Genetics, v. 155, p. 945-959.

Quist, M. C., Pegg, M. A., and DeVries, D. R., 2012, Age and Growth in Zale, A.V., Parrish, D.L., and Sutton, T.M., Fisheries Techniques (3d ed): Bethesda, Maryland, American Fisheries Society Press, p. 223-266.

Rasmussen, J.E., 2011, Status of Lost River sucker and shortnose suckers: Western North American Naturalist, v. 71, p. 442-455.

Rasmussen, J.E., Childress, E. S., 2018, Population viability of endangered Lost River sucker and shortnose sucker and the effects of assisted rearing: Journal of Fish and Wildlife Management, v. 9 no. 2, p. 582-592.

Scoppettone, G.G., 1986, Upper Klamath Lake, Oregon, catostomid research. completion report. U.S. Fish and Wildlife Service, National Fisheries Research Center, Seattle, Washington.

Simon, D., Terwilliger, M.R., and Markle, D.F., 2013, Annual report for project, larval and juvenile ecology of Upper Klamath Lake suckers-2012: Oregon State University Report to Bureau of Reclamation, $88 \mathrm{p}$.

Sutphin, Z., and Tyler, T., 2016, Entrainment of early life-stage of fish from Clear Lake Reservoir into Lost River: Bureau of Reclamation internal report, $25 \mathrm{p}$.

Terwilliger, M.R., Reece, T., and Markle, D.F., 2010, Historic and recent age structure and growth of endangered Lost River and shortnose suckers in Upper Klamath Lake, Oregon: Environmental Biology of Fishes, v. 89, p. 239-252.

Tringali, M.D., Ziemann, D.A., and Stuck, K.C., 2001, Preliminary aspects of genetic management for Pacific Threadfin Polydactylus sexfilis stock enhancement research in Hawaii, in Nakamura, Y., McVey, J.P., Leber, K., Neidig, C., Fox, S., and Churchill, K., eds., Ecology of aquaculture species and enhancement of stocks, Proceedings of the U.S.-Japan Meeting on Aquaculture, 30th, December 3-4, 2001, Sarasota, Florida: Cooperative Program in Natural Resources (UJNR) Technical Report, no. 30 , p. 55-74. 
U.S. Bureau of Reclamation, 2019, Bureau of Reclamation-Water operations hydromet database: Bureau of Reclamation, Mid Pacific Region, Klamath Basin Area Office, site information directly accessible at: https://www.usbr.gov/pn/hydromet/klamath/arcread.html.

U.S. Fish and Wildlife Service, 1988, Endangered and threatened wildlife and plants-Determination of the Status for the Shortnose Sucker and Lost River Sucker: Federal Register, v. 53, no. 137, p. 2713027134.

U.S. Fish and Wildlife Service, 2013, Revised recovery plan for the Lost River Sucker (Deltistes luxatus) and Shortnose Sucker (Chasmistes brevirostris): U.S. Fish and Wildlife Service, Pacific Southwest Region, Sacramento, California. xviii +122 p.

U.S. Geological Survey, 2019, USGS water data for the Nation: U.S. Geological Survey National

Water Information System database, site information directly accessible at: https://nwis.waterdata.usgs.gov.

Winemiller, K.O., and Taylor, D.H., 1982, Inbreeding depression in the convict cichlid Cichlosoma nigrofasciatum (Baird and Girard): Journal of Fish Biology, v. 21, p. 399-402. 

Publishing support provided by the U.S. Geological Survey Science Publishing Network, Tacoma Publishing Service Center

For more information concerning the research in this report, contact the Director, Western Fisheries Research Center

U.S. Geological Survey 6505 NE 65th Street

Seattle, Washington 98115-5016

https://www.usgs.gov/centers/wfrc 
